\title{
RESEARCH
}

Open Access

\section{Evaluation of the Lund deep geothermal exploration project in the Romeleåsen Fault Zone, South Sweden: a case study}

\author{
Jan-Erik Rosberg ${ }^{1^{*}}$ (D) and Mikael Erlström²,3
}

\author{
*Correspondence: \\ jan-erik.rosberg@tg.Ith.se \\ ${ }^{1}$ Engineering Geology, \\ Faculty of Engineering, Lund \\ University, Box 118, 221 \\ 00 Lund, Sweden \\ Full list of author information \\ is available at the end of the \\ article
}

\begin{abstract}
The bedrock of Skåne, the southernmost province of Sweden, has been targeted for geothermal feasibility studies since the late 1970s. An exploration project concerning the geothermal potential in the Romeleåsen Fault Zone was launched outside the town of Lund in 2001. Besides geophysical imaging of the thrust fault zone, the investigations included drilling and investigations of a 3701.8-m-deep exploration well, DGE-1, with the aim to find $>100^{\circ} \mathrm{C}$ warm and hydraulically conductive fractured crystalline bedrock associated to the fault zone. The well penetrates a heavily thrusted and predominantly strongly inclined sedimentary succession in hanging rock blocks along the main fault before entering the fractured crystalline basement at $1946 \mathrm{~m}$, primarily composed of gneiss, granite, and metabasite. This paper represents the first comprehensive description and evaluation of the geological, physical, and hydrological properties of the bedrock at these depths in the Romeleåsen Fault Zone coupled to a geothermal assessment. In addition, the applicability of the four drilling methods used in the crystalline basement section is discussed. The outcome of the DGE-1 well shows significant fracturing in the crystalline bedrock at target depth. The investigations show an average thermal gradient of $22^{\circ} \mathrm{C} / \mathrm{km}$, an average heat flow of $58 \mathrm{~mW} / \mathrm{m}^{2}$, and an average heat production of $5.8 \mu \mathrm{W} / \mathrm{m}^{3}$. The values are relatively high in comparison to thermal conditions noted in other deep wells in the Fennoscandian Shield. However, a bottomhole temperature of around $85^{\circ} \mathrm{C}$ and insufficient fluid production rate made a commercial geothermal system unviable. Despite this, the experiences from drilling and investigations of the crystalline bedrock at several kilometers depth constitute important proxies for assessing the geothermal potential in similar geological settings and for engineered geothermal systems in the crystalline bedrock of south Sweden.
\end{abstract}

Keywords: Crystalline basement, Sorgenfrei-Tornquist Zone, Rock types, Drilling, Hydraulic properties, Thermal properties, Fractures, Seismics, Logging 


\section{Background}

In 2001, Lund Energi AB (now Kraftringen) and the Department of Engineering Geology at Lund University launched a high-enthalpy geothermal exploration project in the fractured crystalline bedrock in the Romeleåsen Fault Zone. The intention of the drilling was to find $>100{ }^{\circ} \mathrm{C}$ hot water for direct heat application to the district heating of the town of Lund. The DGE-1 well reached $3701.8 \mathrm{~m}$ depth and is the third deepest borehole in Sweden. Only the boreholes Gravberg-1 and Stenberg-1 in the Siljan impact structure in central Sweden reach greater depths (Aldahan et al. 1991; Juhlin et al. 1998).

Besides a hydraulic evaluation presented in Rosberg (2007), there is no comprehensive documentation of the results from the investigations in the DGE-1 well. Parts of the information are primarily presented in abstracts to various geothermal conferences (Bjelm 2005, 2006; Rosberg 2006; Alm and Bjelm 2006a, b; Bjelm and Rosberg 2006). However, extensive unpublished information is found in reports, databases, and project documents.

The outcome and experiences from the deep geothermal exploration project in Lund is today highly relevant with respect to evaluating the deep geological conditions in fracture zones such as the Romeleåsen Fault Zone and in the Precambrian crystalline bedrock in general. This statement is based on the increasing interest from Combined Heat and Power (CHP) companies regarding the potential of engineered geothermal systems (EGS) in relatively cold crustal provinces such as the Fennoscandian Shield. In Finland, an ongoing EGS exploration project in connection to a district heating plant in Espoo further promotes feasibility studies regarding EGS projects in the relatively cold Fennoscandian bedrock with temperature gradients of $16-19{ }^{\circ} \mathrm{C} / \mathrm{km}$ (Leary et al. 2017). Technical improvement of the drilling techniques, e.g., percussion drilling using air or water, has also enabled fast drilling of large-diameter wells to great depths in crystalline bedrock.

The increasing interest in assessing and exploiting the geothermal resources from deep reservoirs is consistent with the EU Renewable energy sources directive [Directive 2009/28/EC (2009) of the European Parliament and of the Council]. In 2011, the International Energy Agency (IEA) presented a roadmap stating that, by 2050, more than half of the projected increase in geothermal power production would come from exploitation of ubiquitously available hot rock resources (OECD/IEA 2011). Massachusetts Institute of Technology also stated that the deep geothermal potential is an important component in the process of switching into fossil-free and renewable energy sources for both heating and electricity (MIT 2006). EGS is a conceptual name for a wide range of geothermal systems where the bedrock is stimulated to increase the permeability in the rock formation. With this, completely new geoscientific/technical challenges are to be met. This concerns both evaluation of the potential geothermal resources and developing methods for characterization and modelling these sites before and during the stimulation as well as during the operational phase. For this, it is important to understand the characteristics of the deep geological conditions.

In the Fennoscandian Shield, there are a few boreholes deeper than one kilometre in the crystalline bedrock. Besides DGE-1, the Outokumpu R-2500 research borehole in Finland (Kukkonen 2011), the Kola superdeep borehole on the Kola Peninsula (Arshavskaya et al. 1984), Gravberg-1 and Stenberg-1 in central Sweden (Aldahan et al. 1991), 
and the COSC-1 borehole in the Caledonides (Lorenz et al. 2015) provide information regarding the properties of the Fennoscandian crystalline crust at depths of several kilometers. Outside the Fennoscandian Shield, the KTB and Urach deep boreholes in Germany (Emmermann and Lauterjung 1997; Tenzer et al. 2000; Bucher and Sober 2016) and the Soulz-sous-Forêts borehole in France l (Gérard et al. 2006) constitute valuable references to the outcome of the DGE-1 well.

From an exploration point of view, the main aim of the DGE-1 well was to characterize the thermo-hydraulic properties in the fractured crystalline rock mass. Another aim was to evaluate different drilling methods regarding rate of penetration, overall performance, and applicability in crystalline basement exploration. The DGE-1 well was primarily drilled and tested out of a commercial aspect, which, to some extent, limited the amount of scientific investigations performed. Despite that, there is unique and valuable information, which can be used as proxy for assessing the geothermal prerequisites in the crystalline basement on the southwest margin of the Fennoscandian Shield.

The aim of this paper is, hence, to give a comprehensive description and evaluation of the Lund deep geothermal exploration project focusing on the geological results, drilling experiences and the geothermal properties. In addition, the aim is to some extent compare the results with a selection of similar deep wells in the upper crystalline crust.

\section{Geological basis for the DGE-1 project}

The geological model of the Romeleåsen Fault Zone and the DGE-1 site is based on bedrock maps, seismic investigations, aeromagnetic data, and gravimetrical data (Sivhed et al. 1999; Erlström 2002), as well as regional tectonic studies of the Sorgenfrei-Tornquist Zone and the Fennoscandian Border Zone (e.g., Erlström et al. 1997; Lassen and Thybo 2012).

The province of Skåne lies in the complex buffer zone between the stable Fennoscandian Shield to the north and younger tectonic regimes to the south (Fig. 1a). This has resulted in that Skåne displays a complex subsurface geology, especially across the Sorgenfrei-Tornquist Zone (Fig. 2). During Late Palaeozoic times, Skåne was intersected by NW-SE-oriented deep-seated fault zones delineating the Sorgenfrei-Tornquist Zone, which constitutes the northwest branch of the Tornquist Zone, extending from the Rönne Graben to the Skagerrak Sea northwest of Jylland (Fig. 1a). These fault zones, including the Romeleåsen Fault Zone, were reactivated during Triassic-Jurassic rifting and Late Cretaceous Alpine compression and thrusting (Erlström et al. 1997; Lassen and Thybo 2012). The Late Cretaceous Alpine compression in the crust overprints much of the previous events and has, concerning the Romeleasen Fault Zone, resulted in the formation of a reverse fault system with tilted and hanging rock blocks along the main fault (Fig. 2). Furthermore, during the Neogene, an uplift, in the range of 500-1000 m, occurred in Skåne and the southern margin of the Fennoscandian Shield (Japsen et al. 2002). This resulted in extensive erosion of Palaeozoic and Mesozoic cover strata on the uplifted area. To the southwest of the Romeleåsen Fault Zone, a contemporary subsiding basin (part of the Danish Basin) formed, which in its marginal parts received large amount of the sediments deriving from erosion of the inverted rock block to the northeast (Erlström et al. 1997). A 2000-2500 m-thick Mesozoic succession, dominated by 


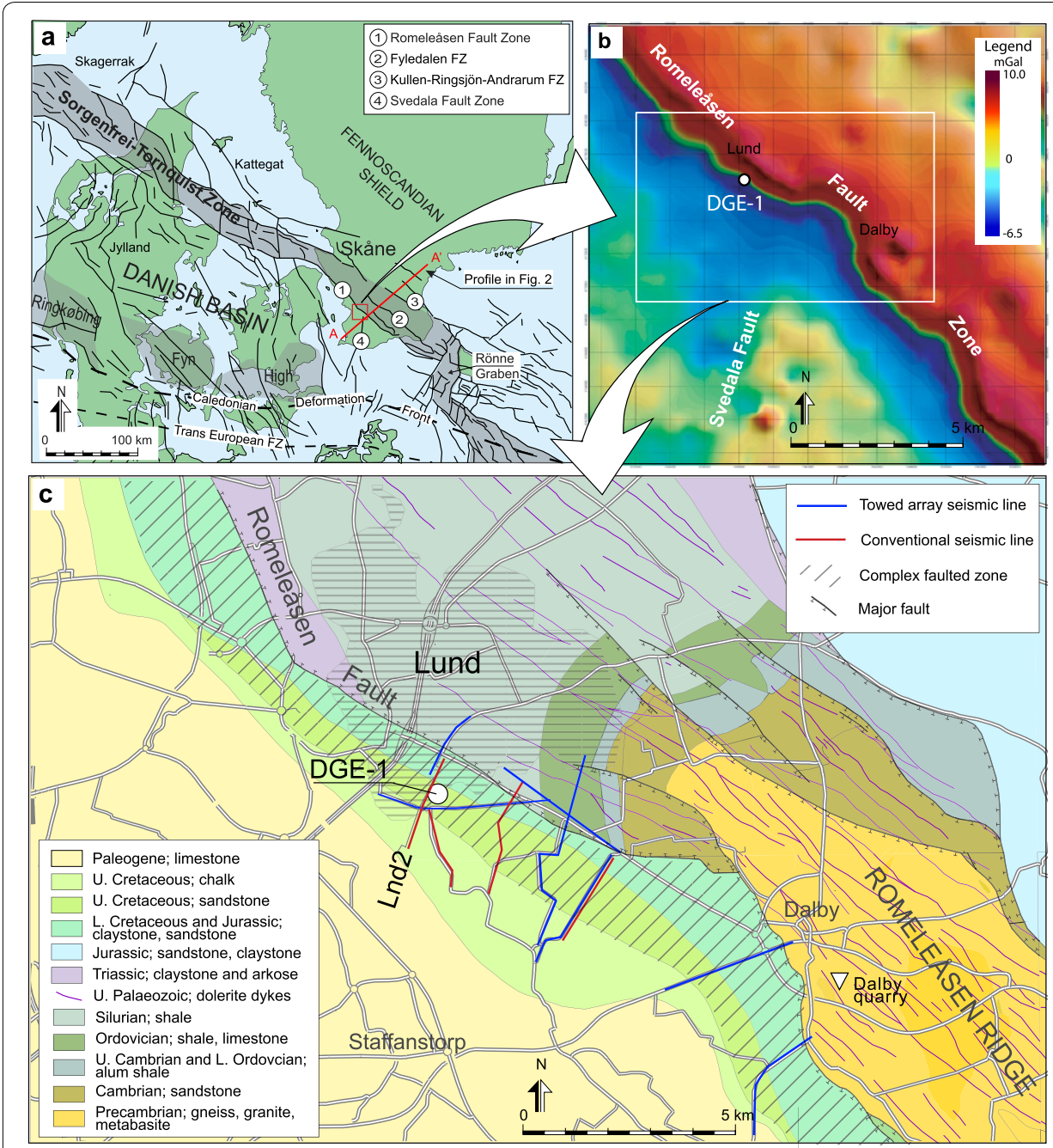

Fig. 1 a Map showing the regional structural framework of the SW Fennoscandian Shield and the Danish Basin, and location of the prospect area (red frame) and profile A-A' shown in Fig. 2. b Bouguer anomaly map showing the gravimetric signature of the Romeleåsen Fault Zone between Lund and Dalby as well as the location of the DGE-1 site, $\mathbf{c}$ bedrock map of the DGE-1 site area (framed area in $\mathbf{b}$ ) and location of the seismic survey lines. Line Lnd 2 is presented in Fig. 4

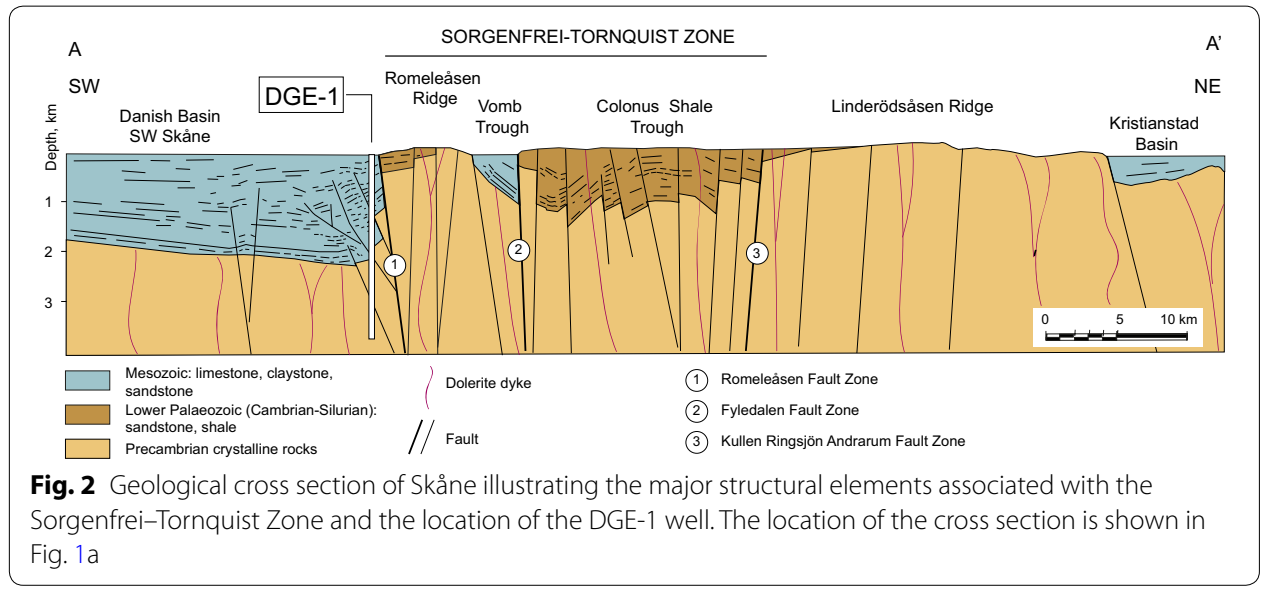


Cretaceous mixed clastic deposits, is here found on top of the Precambrian crystalline basement.

The crystalline basement exposed on the Romeleåsen Ridge is dominated by various gneisses, granites, metabasites, and dolerites (Fig. 1c). The gneisses have ages of about $1700 \mathrm{Ma}$, the metabasite 1200-1700 Ma, and the granites about $1450 \mathrm{Ma}$. The dolerites are related to two different dyke systems, one c. 930-1130 Ma old running NNE-SSW and a younger c. 290-300 Ma old system running NW-SE.

The repeated tectonic events in the Romeleåsen Fault Zone have resulted in a severely fractured crystalline basement, exemplified by exposures in outcrops on the Romeleåsen Ridge (Fig. 3). This also supports the prediction model that the deep-seated Precambrian crystalline basement in the Romeleåsen Fault Zone is similarly fractured and potentially hydraulically conductive.

Consequently, the hypothesis behind the deep geothermal exploration project is that heavily fractured crystalline bedrock is likely to be found at great depths in association to the major faults in the Sorgenfrei-Tornquist Zone (Fig. 1a). In addition, chemical geothermometric studies indicate that there is a relatively high heat flow associated with the Romeleåsen and the Svedala fault zones, and the Fennoscandian Border Zone including the Sorgenfrei-Tornquist Zone (Bjelm et al. 1977; Lassen and Thybo 2012). Furthermore, coincident locations of minor deep-seated earthquakes along faults in the Sorgenfrei-Tornquist Zone, especially in the Kattegat area, indicate that rock stresses in the bedrock are still being released along the main faults (Gregersen et al. 1996). A hydraulically active heavily fractured bedrock system at great depth is also likely present due to the tectonic history of the Sorgenfrei-Tornquist Zone involving several phases of fault reactivation (Erlström et al. 1997; Lassen and Thybo 2012).

Based on the quality and availability of geological information, the selected location for the DGE-1 well was in the southeast part of the town of Lund, a few $100 \mathrm{~m}$ south of the main thrust fault in the Romeleåsen Fault Zone (Fig. 1a-c). The location was besides being within the Romeleåsen Fault Zone favoured by the proximity to the town of Lund

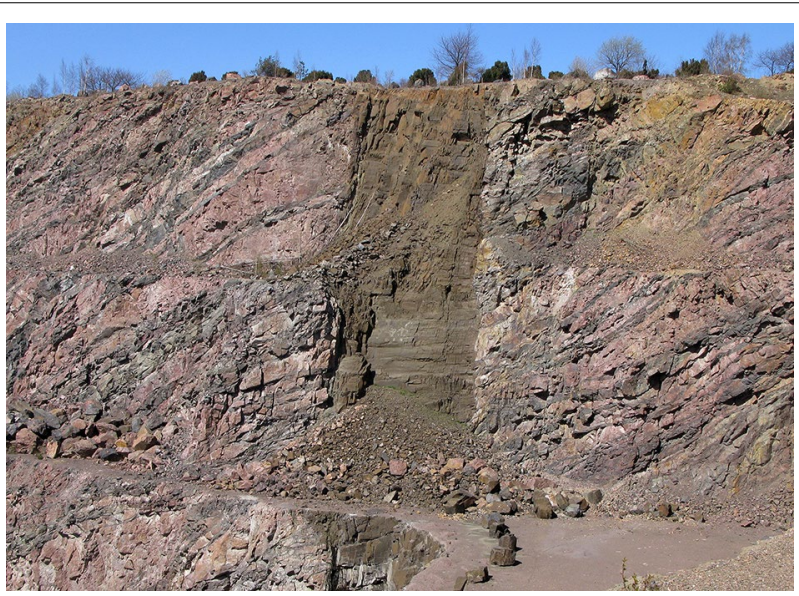

Fig. 3 Photo from Dalby quarry exemplifying the rock mass composition with severely fractured reddish gneiss and numerous variably thick dykes and schlieren of metabasite. The photo also shows a subvertical brownish black Permo-Carboniferous dolerite dyke cutting through the host rock. Photo: L. Johansson 
with its district heating system constituting the potential recipient of the geothermal energy.

\section{Methods}

\section{Seismic imaging of the Romeleåsen Fault Zone}

During the pre-investigations for the Lund deep geothermal project, $32.4 \mathrm{~km}$ highresolution seismic surveys were performed across the fault zone outside the town of Lund (Figs. 1c, 4). The main survey included ten lines performed on roads by Rambøll AS using a towed array land streamer unit with conventional P-wave geophones and a 64-channel StrataVisor NZ seismograph. The energy source was a $3500 \mathrm{~kg}$ Minivibrator

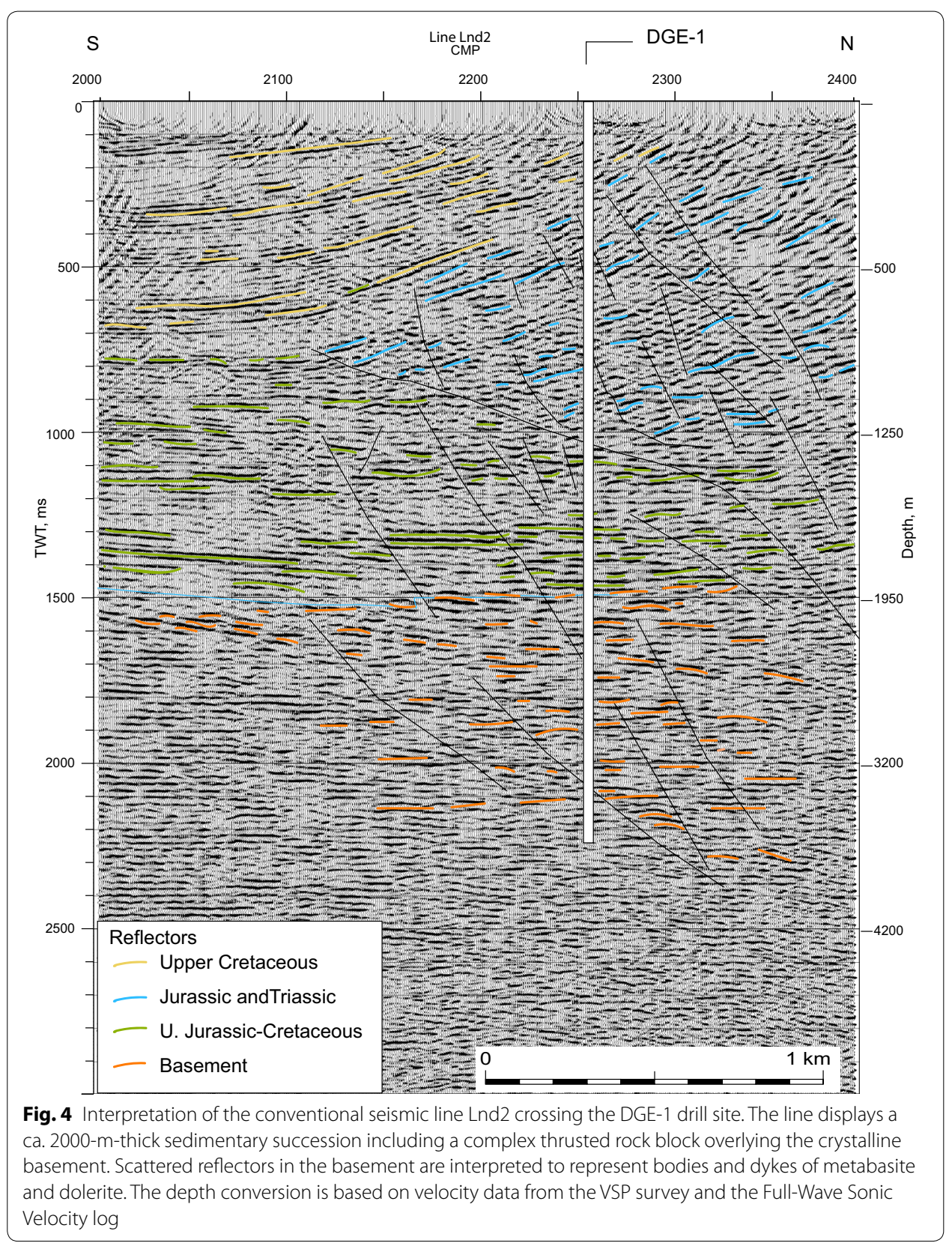


generating frequencies up to $550 \mathrm{~Hz}$. In addition, five conventional seismic lines were performed using an active 120 geophone group array of $1190 \mathrm{~m}$ and a Failing Y1100 vibration truck with a hold down weight of 13.5 tonnes (Alm and Bjelm 2006a). The towed array survey gave primarily information on the fault and rock block configuration of the shallow part of the fault zone down to c. $1000 \mathrm{~m}$ depth, while the conventional survey gave complementary deep information including the upper part of the crystalline basement (Fig. 4). On some of the conventional lines, there are also reflectors identified in the basement interval.

\section{Drilling operation}

The drilling of DGE-1 started on October 19, 2002 and finished on March 19, 2003. The drill rig used was T-61, type Dreco $1000 \mathrm{M}$, with a top drive. The total depth reached was $3701.8 \mathrm{~m}$ of which the lower $1756 \mathrm{~m}$ were drilled in the crystalline basement. All depths given are measured from the drill floor (Kelly bushing), located $7.1 \mathrm{~m}$ above the ground level. The well is completed with casing down to $3198 \mathrm{~m}$ and has an $81 / 2^{\prime \prime}$ open main target section down to the total depth. Table 1 and Fig. 5 summarize the used drill bit sizes and drilling methods as well as design and completion of the well.

Four different drilling methods were used: conventional mud rotary drilling, air rotary drilling, percussion drilling using air, and percussion drilling using mud (Table 1). Conventional mud rotary drilling was used in the sedimentary succession as well as in parts of the crystalline basement, while the other methods were only applied in the crystalline basement. Initially, the mud rotary drilling was performed using either bentonite mud or a $\mathrm{KCl}$ /polymer-based mud. Three compressors and boosters with a combined flow rate of around $3600 \mathrm{cfm}\left(102 \mathrm{~m}^{3} / \mathrm{min}\right)$ and a maximum pressure of 140 bar were used during the air drilling operation. A more detailed description of the drilling can be found in the final well report (Howard-Orchard 2003).

Table 1 Drill bit sizes and drilling methods used in DGE-1

\begin{tabular}{|c|c|c|}
\hline Depth interval & Drill bit size & Drilling method \\
\hline $0-23 \mathrm{~m}$ & $40^{\prime \prime}(1016 \mathrm{~mm})$ & Auger drilling \\
\hline $23-165 m$ & $\begin{array}{l}\text { 26" (660 mm) and 36" } \\
\text { (914 mm) hole opener }\end{array}$ & Mud rotary drilling \\
\hline $165-1020 \mathrm{~m}$ & $26^{\prime \prime}(660 \mathrm{~mm})$ & Mud rotary drilling \\
\hline 1020-2044 m & $1712^{\prime \prime}(445 \mathrm{~mm})$ & Mud rotary drilling \\
\hline $2044-2119 m$ & $12^{1 / 4^{\prime \prime}}(311 \mathrm{~mm})$ & Mud rotary drilling \\
\hline $2119-2878 m$ & $12^{1 / 4^{\prime \prime}}(311 \mathrm{~mm})$ & Air rotary drilling \\
\hline 2878-2972 m & $12^{1 / 4 \prime} 4^{\prime \prime}(311 \mathrm{~mm})$ & Percussion drilling using air \\
\hline 2972-3365 m & $12^{1 / 4^{\prime \prime}}(311 \mathrm{~mm})$ & Air rotary drilling \\
\hline $3198^{\mathrm{a}}-3666 \mathrm{~m}$ & $81 / 2 " 1$ (244 mm) & Mud rotary drilling using lightweight polymer mud \\
\hline $3666-3675$ m & $81 / 2 "(244 \mathrm{~mm})$ & Percussion drilling using mud \\
\hline $3675-3701.8 m$ & $81 / 2^{\prime \prime}(244 \mathrm{~mm})$ & Mud rotary drilling using lightweight polymer mud \\
\hline
\end{tabular}

The crystalline basement was reached at $1946 \mathrm{~m}$ depth

a Due to whipstock installation

b Mud weight between 1.02 and $1.05 \mathrm{~g} / \mathrm{cm}^{3}$ 


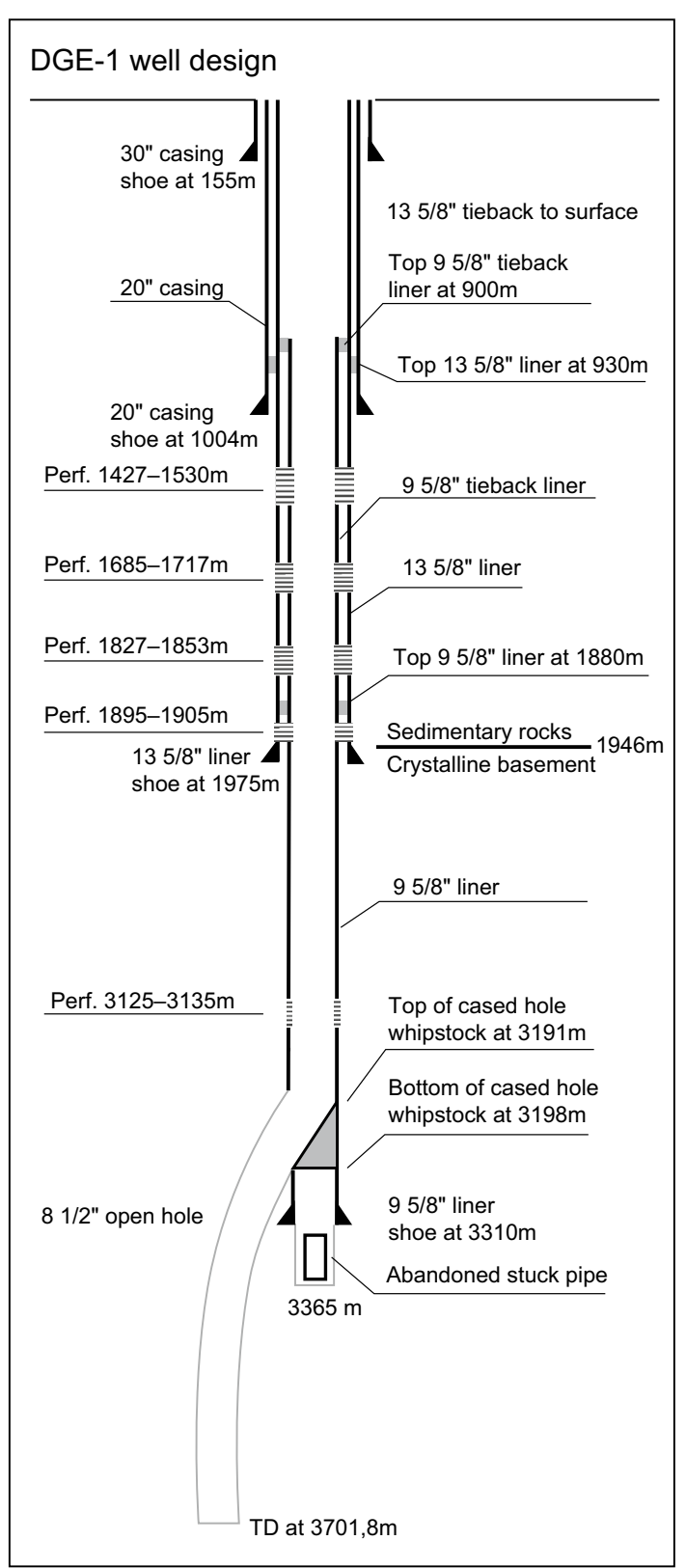

Fig. 5 Illustration of the DGE-1 well design [Modified from Howard-Orchard (2003)]. Perforations in the sedimentary succession between 1427 and $1905 \mathrm{~m}$ were conducted after the testing and evaluation of the crystalline basement. The results from the testing of the sedimentary succession are presented in Rosberg $(2006,2007)$

\section{Mud logging}

The characterization of the rock types occurring in the DGE-1 well is merely based on descriptions of cuttings, since coring was not performed. Cuttings were sampled every $3 \mathrm{~m}$ by the mud logging company (Geo-DATA, Hannover) and the on-site rock type descriptions were performed by geologists from the Geological Survey of Sweden. The samples from the Precambrian crystalline basement represent often a 
mixture of rock material and small cuttings due to the applied air rotary or percussion drilling techniques. The air flow made it also difficult to define an exact depth for the cuttings sampled at the surface. Denser sampling intervals were tested, but it was not operationally feasible to accomplish.

\section{Geophysical wire-line logging}

Five open-hole logging runs were performed in the well (Table 2). The logging performed in the sedimentary rock section included a standard suite of logs for lithological characterization. In addition, a dipmeter log was run which gave valuable information on the inclination of strata in the faulted zone. Furthermore, a Vertical Seismic Profiling (VSP) survey was also carried out from 2070 to $45 \mathrm{~m}$, prior to the installation of the 13 $5 / 8$ " (346 mm) casing. The survey was performed with a sampling interval of $15 \mathrm{~m}$ and source offset of $17 \mathrm{~m}$. The results from the VSP survey were primarily used to get at a correct depth conversion of the conventional surface seismic surveys.

In addition, three production logging runs (PLT) were conducted in the crystalline basement. One was conducted before the $95 / 8^{\prime \prime}$ casing was installed at $3198 \mathrm{~m}$ and the other two between 3198 and $3701.8 \mathrm{~m}$. Airlifting in the open-hole section was used for producing water while logging.

\section{Temperature survey and thermal properties}

A temperature survey was conducted 3 months after the well was completed, using a slickline with a depth encoder and a memory gauge. The memory gauge was a Metrolog iGauge with a pressure range between 0 and 650 bar and temperature range between 0 and $150{ }^{\circ} \mathrm{C}$. The temperature accuracy was $0.3^{\circ} \mathrm{C}$ and the used sampling rate was set to one second. The tool was lowered to the bottom of the well where the tool was left for

Table 2 Summary of the electrical logging runs conducted in DGE-1

\begin{tabular}{|c|c|c|c|}
\hline Run\# & Depth interval & Hole diameter & Type of log \\
\hline 1 & $2.2-1012.5 \mathrm{~m}$ & $26^{\prime \prime}(660 \mathrm{~mm})$ & $\begin{array}{l}\text { Spontaneous potential (SP) } \\
\text { Gamma ray } \\
\text { Borehole compensated sonic } \\
\text { XY-caliper }\end{array}$ \\
\hline 2 & $1012.5-2044 \mathrm{~m}$ & $171 / 22^{\prime \prime}(445 \mathrm{~mm})$ & $\begin{array}{l}\text { Gamma ray } \\
\text { Borehole compensated sonic } \\
\text { Six-electrode dipmeter } \\
\text { Temperature }\end{array}$ \\
\hline 3 & 1975-3322 m & $121^{1 / \prime}(311 \mathrm{~mm})$ & $\begin{array}{l}\text { Gamma ray } \\
\text { Borehole compensated sonic } \\
\text { Full-wave sonic image waveform } \\
\text { Compensated spectral gamma ray } \\
\text { Production logging tool (PLT) }\end{array}$ \\
\hline $4-5$ & $3180-3701 \mathrm{~m}$ & $81 / 2^{\prime \prime}(244 \mathrm{~mm})$ & $\begin{array}{l}\text { Caliper } \\
\text { Gamma ray } \\
\text { Borehole compensated sonic } \\
\text { Full-wave sonic image waveform } \\
\text { Compensated spectral gamma ray } \\
\text { Gamma ray cement bond log } \\
\text { Production logging tool (PLT) }\end{array}$ \\
\hline
\end{tabular}

All logging runs were conducted in open hole 
$24 \mathrm{~h}$ before it was pulled upwards. Below $3000 \mathrm{~m}$, the tool stopped for a measurement for $1 \mathrm{~min}$ every $25 \mathrm{~m}$. Above $3000 \mathrm{~m}$, a 1-min measurement was made every $50 \mathrm{~m}$.

The heat production $(A)$ for the crystalline section $(1977-3697 \mathrm{~m})$ is calculated using the concentrations of the radiogenic isotopes of uranium $(\mathrm{U})$, thorium $(\mathrm{Th})$, and potassium (K) from the spectral gamma ray log. Since most of the geothermal heat generated in the crust is derived from the decay of these isotopes (Wollenberg and Smith 1987), the use of gamma ray logging data for evaluating the heat productivity in deep boreholes in the upper crust is today a common approach, which is exemplified by the work of Majorowicz et al. (2014) and Jiang et al. (2016) in deep boreholes in Western Canada and China.

The radiogenic isotope concentrations in the DGE-1 well were measured using a compensated gamma ray spectrometer logging tool operated by Halliburton. Our calculations, as the ones by Majorowicz et al. (2014) and Jiang et al. (2016), are based on the work by Bücker and Rybach (1996) and their empirical formula on heat production (Eq. 1):

$$
A=10^{-5} * \rho\left(9.52 * \mathrm{U}_{\mathrm{ppm}}+2.56 * \mathrm{Th}_{\mathrm{ppm}}+3.48 * \mathrm{~K}_{\text {percent }}\right) .
$$

The rock density values $(\rho)$ are normally taken from density logging data or measurements on cores. However, in DGE-1, none of these sources of information exist. Therefore, we used rock densities on gneiss, granite, and basic rocks from the Precambrian crystalline basement on the adjacent Romeleåsen Ridge. The density data come from the geophysical database at the Geological Survey of Sweden. The average density for gneissgranite is in these data $2635 \mathrm{~kg} / \mathrm{m}^{3}$ and $3008 \mathrm{~kg} / \mathrm{m}^{3}$ for the metabasite-amphibolite.

The heat flow has been calculated using thermal conductivity data from measurements on rock samples from bedrock on the adjacent Romeleåsen Ridge since no cores are available from the DGE-1 well. The analyses were performed at the Geological Survey of Sweden by Andolfsson (2013) using an optical thermal conductivity scanner (cf. Popov et al. 1999). In total, there are 25 analyses on similar rock types that occur in the DGE borehole.

The results give an average thermal conductivity $\left(k_{0}\right)$ of $2.9 \mathrm{~W} /(\mathrm{m} \mathrm{K})$ for the gneissgranite rocks and $2.5 \mathrm{~W} /(\mathrm{m} \mathrm{K})$ for the amphibolite-metabasite (Andolfsson 2013). Based on the relative occurrence of the these dominating rock types, we calculated an average weighted thermal conductivity $\left(k_{0}\right)$ of $2.8 \mathrm{~W} /(\mathrm{m} \mathrm{K})$ for the crystalline section in the DGE-1 well. The correction formula (Eq. 2) presented by Chapman and Furlong (1992) was used to compensate the thermal conductivity $\left(k_{0}\right)$ measured at room temperature $\left(20{ }^{\circ} \mathrm{C}\right)$ to in situ conditions $\left(k_{\text {in-situ }}\right)$, which depend on borehole temperature $(T)$ and depth $(z)$ :

$$
k_{\text {(in-situ })}=k_{0}(1+c z) /(1+b(T-20)) .
$$

Since the drilled Precambrian section in the DGE-1 well is dominated by gneissicgranitic rocks, we use the same coefficient values for $c$ and $b$, representative for granitic upper crust, as the ones given by Chapman and Furlong (1992), i.e., $c=1.5 \times 10^{-6} / \mathrm{m}$ and $b=1.5 \times 10^{-3} / \mathrm{K}$.

The heat flow $(Q)$ is calculated using Eq. 3. The depth compensated $k$ values $\left(k_{\text {in situ }}\right)$ are multiplied by the calculated temperature gradients $T_{\text {(grad) }}$ for $25-\mathrm{m}$ intervals between 2000 and $3600 \mathrm{~m}$ : 


$$
Q=k_{(\text {in-situ })} \times T_{(\text {grad })} .
$$

\section{Hydraulic testing}

The hydraulic testing is only described for the crystalline basement section between 3198 and $3701.8 \mathrm{~m}$, which corresponds to the open-hole section. Information about the conducted test operation of the later performed perforations in the sedimentary sequence is found in Rosberg $(2006,2007)$ (see Fig. 5). The initial hydraulic tests in the crystalline basement section were performed by airlifting. These tests were performed directly after the well was completed, and no well cleaning was made before the testing. An air-sub was attached to the drill string and placed at $3690 \mathrm{~m}$ depth close to the bottom of the well. Thereafter, the air-sub was positioned in the cased section around $3100 \mathrm{~m}$. No downhole pressure and temperature measurements were performed during the airlifting. The flow rate, applied air pressure, and air flow were measured on surface. This test set-up is described in Rosberg (2006, 2007). All 19 airlifts were conducted over a period of 5 days.

In addition, a 3-day long period with injection and fall-off tests were conducted. The injection pressure and the injection rate were measured at the surface. The open-hole basement section was tested as one unit and earlier produced formation fluid was reinjected during the test. In other words, no zones in the basement were sealed off and tested separately.

\section{Water sampling and chemical analysis}

Sampling of the formation fluid retrieved at the surface was performed during the airlift operation of the open-hole section between 3198 and $3701.8 \mathrm{~m}$. This means that the formation fluid was oxygenated before it was sampled. Unfortunately, no in situ fluid sampling was conducted. A standard chemical characterization was made at the drill site, using a portable electrical conductivity and $\mathrm{pH}$ measuring devices and Photometer LF2400. Many of the analyzed concentrations were higher than the measuring range of the photometer; in those cases, the sample was diluted for enabling the measurement. Three samples were sent to a certified laboratory for chemical elements analysis using Inductively Coupled Plasma Atomic Emission Spectroscopy (ICP-AES) and High-Resolution Inductively Coupled Plasma Mass Spectrometry (HR-ICP-MS).

\section{Results and discussion}

\section{Geophysical signature of the Romeleåsen Fault Zone}

The extension of the Romeleåsen Fault Zone is clearly marked in aeromagnetic and gravity maps of Skåne (Sivhed et al. 1999; Erlström et al. 2004). Figure 1b shows an example of a Bouguer gravity anomaly map of the Lund area displaying the very distinct outline of the fault zone. Filtration of the gravity data across the fault zone, separating the shallow gravity component down to approximately $500 \mathrm{~m}$ depth from the deeper one, gives a gravity maximum that moves to the northeast for the deeper data. This fits with a thrust fault where the hanging wall constitutes the Romeleåsen Ridge and a foot wall with thrusted hanging rock blocks bordering the Danish Basin to the southwest.

The configuration of the fault zone is exemplified in the interpreted seismic line Lnd2 that crosses the fault zone and the DGE-1 site (Fig. 4). The subsurface framework of 
the thrust fault is here an approximately $1.5-\mathrm{km}$-wide zone of hanging rock blocks with strongly dipping sedimentary strata, thrusted above the footwall crystalline bedrock and sedimentary cover strata. The thrusted succession is primarily composed of Upper Triassic and Jurassic strata that were originally deposited in a basin northeast of the main fault. Alpine fault reactivation, compression, and inversion of the Sorgenfrei-Tornquist Zone in Skåne thrusted these strata to the southwest. The thrusted block is superimposed on a succession of Lower Cretaceous strata overlying the crystalline basement (Fig. 4). Erosion of the uplifted area, including the thrusted zone and the area northeast of the Romeleåsen Fault Zone, e.g., the Romeleåsen Ridge, resulted in deposition of thick sandstone-dominated successions of Campanian age along the margins of the Danish Basin. Since the mid 1980s, this sandstone-dominated succession, i.e., the Lund Sandstone, has been utilized as a low-enthalpy geothermal aquifer in Lund (Erlström 1990; Bjelm and Lindeberg 1994).

The seismic reflectivity of the crystalline basement from c. $2000 \mathrm{~m}$ and downwards is poor. Scattered discontinuous sub-horizontal reflectors are interpreted to represent occurrences of bodies and dykes of metabasite and dolerite. The faults in the basement are poorly seen in the seismics. Therefore, the deeper configuration of the Romeleasen Fault Zone in the Lund area is not clarified by the seismic survey. However, interpretations of seismic data from the BABEL line in the Bornholm Gat to the southeast give that the Romeleåsen Fault Zone constitute a deep-seated listric fault which breaks off at the interface between the upper crust and the mantle at great depth beneath the south part of the Fennoscandian Shield (Thomas and Deeks 1994).

The quality of the interpretation of the surface seismics was greatly improved by the results from the VSP survey, especially the definition of the basement level. Surprisingly low velocities for the sedimentary succession (c. 2000-2800 m/s) explain why the basement in DGE-1 was reached at 1946 m, a significantly higher level than expected. Based on the velocity assessment done during the conventional surface seismic survey, the basement level was initially anticipated at c. 2350 m. The Full-Wave Sonic Velocity logging in the basement gives velocities averaging around $5500 \mathrm{~m} / \mathrm{s}$. Zones with metabasite and dolerite are often indicated by even higher and fractured zones with significantly lower velocities.

\section{Experiences from the drilling operation}

When drilling the crystalline basement, it was experienced that the mud rotary drilling was the least efficient technique considering the Rate of Penetration (ROP). The ROP was, on average, $0.6 \mathrm{~m} / \mathrm{h}$, while the air rotary drilling with button bits gave an average ROP between 2 and $4 \mathrm{~m} / \mathrm{h}$. However, a ROP as high as $15 \mathrm{~m} / \mathrm{h}$ was recorded, e.g. overly high penetration rates for an appropriate hole cleaning, at $3365 \mathrm{~m}$ (cf. Fig. 6). Consequently, the drill string got stuck at that depth which in turn led to a forced action to cut off the drill string assembly. A whipstock (cf. Bruton et al. 2014) was, thereafter, installed at $3191 \mathrm{~m}$ and the drilling by sidetracking past the abandoned section. Additional information about the penetration rates coupled to the various drilling techniques can be found in Bjelm (2006).

Percussion drilling using air was tested over a short interval between 2878 and $2978 \mathrm{~m}$, as part of a R\&D project to test various drilling methods for deep drilling in crystalline 


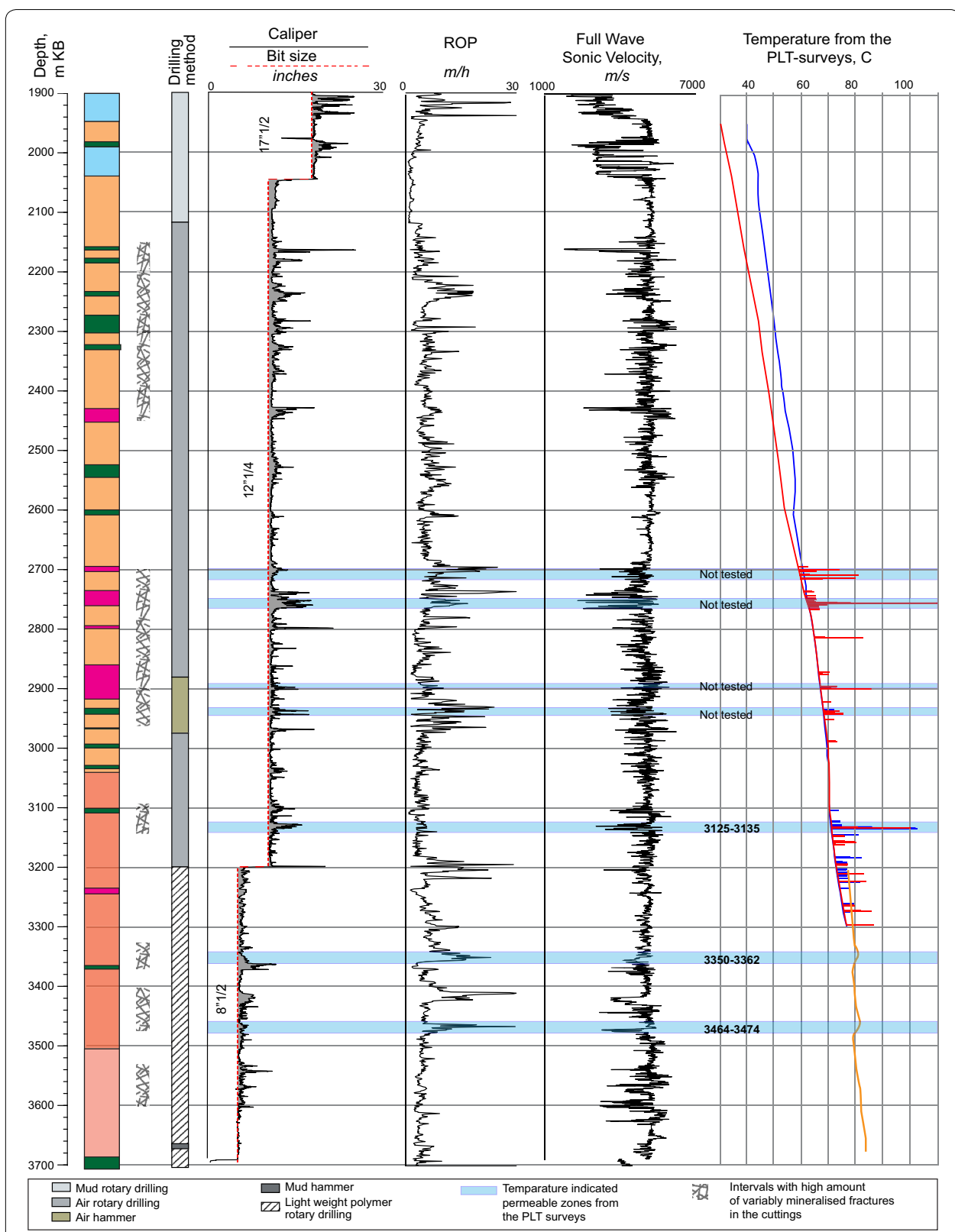

Fig. 6 Composite log illustrating lithology, drilling method, rate of penetration (ROP), caliper, full-wave sonic velocity, and the PLT surveys. Intervals with noted increased fracturing and interpreted hydraulically conductive zones are marked. The lithology legend is shown in Fig. 7

basement rocks. A Numa Challenger 125 down the hole hammer was used with a $12^{1 / 4^{\prime \prime}}$ percussion drill bit. The average penetration rate was $2.4 \mathrm{~m} / \mathrm{h}$, but rates as high as 8-10 $\mathrm{m} / \mathrm{h}$ were recorded. The test terminated sooner than planned due to a loosened main valve in the downhole hammer. Operational remarks in the final well report stated that it was difficult to apply the light bit weights between one and three tonnes, and that it was hard to judge at the surface whether or not the hammer was working properly. This was likely caused by high torque from the borehole wall masking the hammer frequency. A main advantage using percussion drilling compared to air rotary drilling is 
that percussion drill bits last longer than rotary drill bits. In other words, the time for replacing drill bits can be reduced and, consequently, the drilling cost.

Percussion drilling using mud or so-called mud hammer drilling technique was also tested. The Wassara prototype mud hammer was tested between 3666 and $3678 \mathrm{~m}$. The test showed penetration rates between 3 and $5 \mathrm{~m} / \mathrm{h}$. A washout damage of the drill pipe led to the limited test. The operational remarks note that the hammer is sensitive to clogging by fine particles suspended in the mud, which puts high requirements on the performance of the mud cleaning equipment. Today, even higher penetration rates are reported for deep drillings in hard rocks using mud/water hammers, e.g., Wittig et al. (2015) present penetration rates around $10 \mathrm{~m} / \mathrm{h}$ down to $4500 \mathrm{~m}$ depth in South Korea.

Drilling methods using air as a drilling fluid proved to be the most efficient when drilling in crystalline basement rocks with a rate of penetration up to four times higher than conventional mud-based rotary drilling. A prerequisite for the effectiveness of air drilling is a low inflow of water into the wellbore while drilling. Despite the rental costs for the compressors and operators being high, these are compensated by greater cost savings if the ROP is four times higher in comparison to other drilling techniques. Today, even higher penetration rates are obtained from deep percussion drilling using air in crystalline rock, e.g., according to Malin (2018) $240 \mathrm{~m}$ was drilled in $24 \mathrm{~h}$ in a deep drilling project in Finland. The cost savings can be even higher if percussion bits with a longer bit life than conventional rotary bits are used. In DGE-1, a total of 30 tri-cone drill bits were used for drilling the crystalline basement rock section and the longest footage for a drill bit was $152 \mathrm{~m}$, and it was changed after $41.1 \mathrm{~h}$ of drilling.

The total cost for the DGE-1 well including the post drilling test operations was 122.1 MSEK (14.2 MUSD using the exchange rate in March 2003), around 50 MSEK higher cost than initially estimated. Only the drilling cost was around 94.6 MSEK. One reason for the increased cost was related to the c. 28-day delay caused by the sidetracking operation when the drill string got stuck at $3365 \mathrm{~m}$ because of overly high penetration rates in combination with insufficient hole cleaning.

\section{Geophysical logging}

Figures 6, 7 show composite logs for the crystalline basement section with logging curves for the Caliper, Full-Wave Sonic Velocity and compensated spectral gamma ray logs performed in runs number three (1954-3222 m), and four and five (3180-3701 m). Especially, the compensated spectral gamma ray log gives valuable information usable for comparison with the well-site description for the cuttings. The ratios between potassium, uranium, and thorium are very significant markers for changes in mineralogy, i.e., rock types. The metabasites are, for instance, clearly marked by high $T \mathrm{~h} / \mathrm{K}$ and $\mathrm{U} / \mathrm{K}$ ratios in the log motifs. There is also an evident correlation between larger hole sizes and low P-wave velocities, regarding the occurrence of zones of weakness and fracturing in the rock, see the depth interval between 2750 and $2760 \mathrm{~m}$ (Fig. 6). This is also complemented by information from the ROP curve, keeping in mind that various drilling methods were used.

Three hydraulically conductive zones, 3125-3135 m, 2935-2945 m, and 2750-2760 m, were identified in the first PLT survey. These zones were later cased-off, which was a forced action to enable the installation of the casing whipstock, which was necessary 


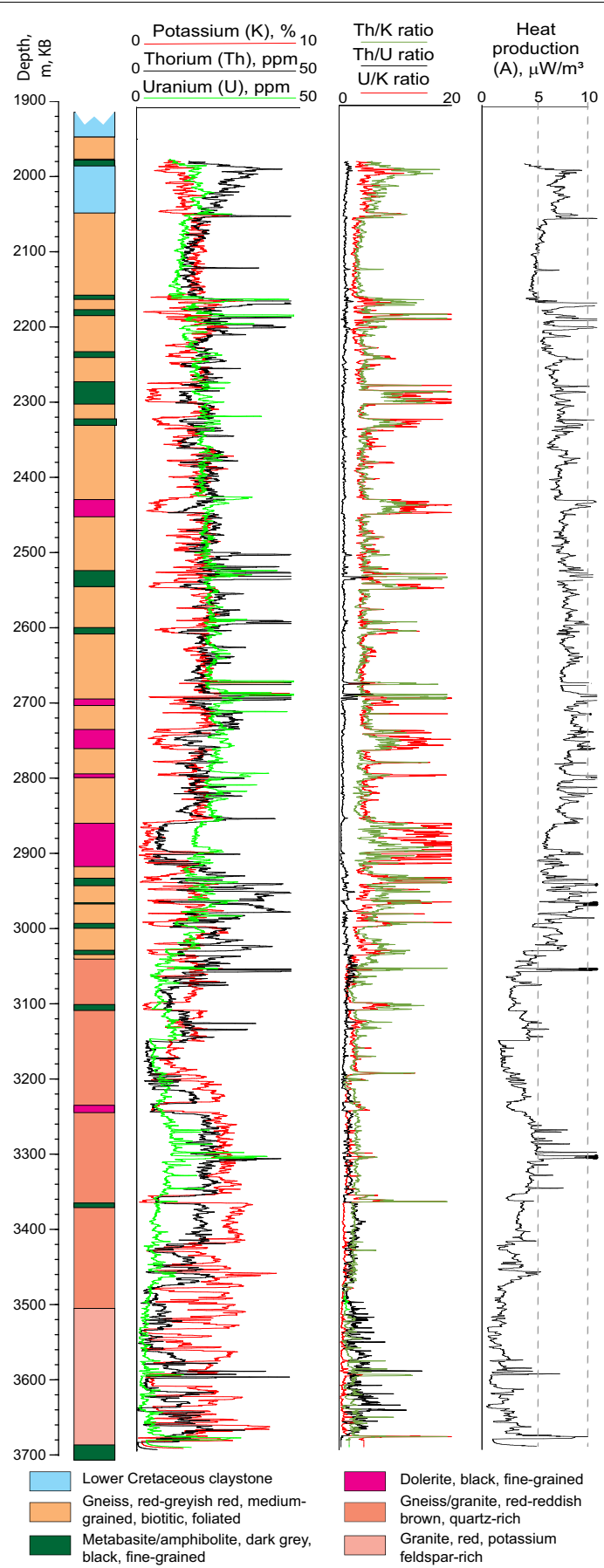

Fig. 7 Composite log of DGE-1, showing lithology, spectral gamma ray logs, and calculated heat production

to be able to drill down to the target depth. Two additional potential production zones 3350-3362 m and 3464-3474 m were identified over the deeper section. Anomalies in the temperature readings were especially informative in identifying the zones (Fig. 6). However, it is only the zones with a different temperature from the wellbore fluid that 
can be identified. Results from the PLT surveys in the basement as well as the later performed test in the sedimentary succession are presented in Alm and Bjelm (2006b).

\section{The geology of the DGE-1 well}

The major rock type intervals were easily identified in the cuttings. Even if the samples represent mixed material, it was possible to make a frequency assessment of dominating rock types over a certain interval as well as detecting the first appearance of changes in the cuttings related to the drilling entering a new rock type. However, the occurrence of few-meter-wide dykes and bodies of, e.g., metabasite and dolerite were often missed by only examining the cuttings. By combining the descriptions of the cuttings and the results from the geophysical wire-line logs, a litholog was constructed where even thinner intervals could be resolved and assigned to a certain rock type.

A composite litholog compiled by the Geological Survey of Sweden, describing both the sedimentary and crystalline succession, is presented in the DGE-1 well-site report (Erlström and Sivhed 2003).

This study presents a review and partial revision of the lithology presented by Erlström and Sivhed (2003). The revised Precambrian section (Fig. 7) is based on a re-examination of the cuttings as well as comparing the occurrence of various rock types with the results from the compensated spectral gamma ray log.

\section{The sedimentary bedrock succession}

Below 47 m of Quaternary deposits, the DGE-1 enters a complex succession of Upper Cretaceous, Lower Jurassic, Upper Triassic, and Lower Cretaceous rocks before reaching the Precambrian crystalline basement at $1946 \mathrm{~m}$ depth. The zone with hanging rock blocks along the main reverse fault, which is identified in the seismic survey, is clearly reflected in the penetrated sedimentary succession. Repeated rock sequences as well as reverse stratigraphical orders are common features. The upper $164 \mathrm{~m}$ of the sedimentary succession consists of Upper Cretaceous (Campanian) medium- and coarsegrained sandstone beds representing deposits formed after the main Alpine inversion and thrusting, i.e., the Lund Sandstone (Erlström 1990). Below $211 \mathrm{~m}$ depth, a complex thrusted succession of tilted and deformed Lower Jurassic and Upper Triassic claystone- and sandstone-dominated strata was penetrated down to $1475 \mathrm{~m}$ depth. Below the thrusted block, the borehole penetrates a conformal horizontally layered succession of Lower Cretaceous-Santonian strata overlying the crystalline basement. However, Lower Cretaceous claystone occurred again between 1985 and 2050 m, indicating that the borehole cuts through a zone with faulted hanging basement rock blocks resulting in the repeated occurrence of sedimentary strata before entering a continuous crystalline basement.

\section{The Precambrian basement}

Various types of gneiss dominate the Precambrian basement. These are generally orthogneisses of granitoid origin. Red-to-greyish red, fine- and medium-grained gneiss dominates down to $3040 \mathrm{~m}$ depth. The gneiss is typically quartz-rich, biotite-rich, strongly foliated, granulitic, and the plagioclase is commonly transformed into albite. This is 
interpreted as indicate de-quartzification related to the intrusion of the Permo-Carboniferous NW-SE-oriented dolerite dykes.

The gneiss contains numerous irregular bodies and lenses of black, dark grey, or greyish black, fine-grained metabasite. Intervals with black-to-greyish black, fine-grained dolerite are also found. The distinction between metabasite and dolerite in the cuttings is clear, since the dolerite commonly shows a typical ophitic texture, while the metabasite contains hornblende and biotite. The occurrences of basic rocks are also clearly marked in the compensated spectral gamma ray log (Fig. 7). However, both rock types show similar spectral gamma ray log signatures with low potassium concentrations and high $\mathrm{Th} / \mathrm{K}$ and $\mathrm{U} / \mathrm{K}$ relationships which makes it difficult to distinguish where they occur in the basement section. Our interpretation and distinction between metabasite and dolerite are, besides the cuttings analyses, based on the U/K relationship which is slightly greater for the dolerites in comparison to the metabasites (cf. Sivhed et al. 1999). The proxy for this is besides chemical data from outcrops on the Romeleåsen Ridge also the log signature of a verified $56 \mathrm{~m}$-thick dolerite dyke between 2862 and $2918 \mathrm{~m}$ depth. An increasing amount of fractures are often observed in the bedrock in connection to the basic rock intervals, which is indicated by the results from the Caliper and Velocity logs and the ROP data (Fig. 6). The occurrences of metabasite, dolerite, and fractured zones are interpreted to generate the relatively high frequency of discontinuous reflectors in the basement within this interval (Fig. 4). Metabasite and dolerite comprise c. $35 \%$ of the rock mass down to $3040 \mathrm{~m}$.

The gneiss-dominated interval between 1946 and $3040 \mathrm{~m}$ is also characterized by a relatively higher uranium concentrations in comparison to the underlying interval between 3040 and $3504 \mathrm{~m}$. In this underlying interval, the gneiss is characteristically fine-grained, quartz-rich, and poorly foliated with only minor amount of dark minerals. There is also a significant decrease in the amount of metabasite and dolerite that furthermore signifies the interval.

Below $3504 \mathrm{~m}$, there is a characteristic change into a red-to-reddish brown, mediumgrained feldspar-rich granite. The log motif over this interval clearly distinguishes it from the other basement rock types in the DGE-1 as well. The rock type is characterized by relatively low uranium and thorium readings in the spectral gamma ray log, while the potassium values are significantly higher. This gives a relatively high $\mathrm{Th} / \mathrm{U}$ ratio which furthermore characterizes the rocks over this interval. The DGE-1 well ends in a metabasite at $3701.8 \mathrm{~m}$ depth.

\section{Fracturing}

Microfractures variably filled or coated with calcite, Fe-, Mg-carbonate, sulphides, epidote, fluorite, and Fe-oxyhydroxides are frequently identified in the cuttings. Intervals with relatively higher amount of fractured sections are found at $2150-2440 \mathrm{~m}, 2700$ $2965 \mathrm{~m}, 3090-3135 \mathrm{~m}, 3330-3360 \mathrm{~m}, 3410-3475 \mathrm{~m}$, and 3525-3600 m (Fig. 6). The zones are commonly associated with sections where there is a higher frequency of metabasite and dolerite.

The character and mineralogy of the fractures and fracture fillings in the DGE-1 basement interval is very similar to the ones described from basement rocks exposed in the 
Dalby quarry on the Romeleåsen Ridge (Figs. 1c, 3). Besides open fractures, the basement at Dalby quarry displays high amount of variably sealed fractures with 15 fracture-filling mineral phases representing four generations (Halling 2015). The frequent occurrence of calcite and sulphide mineralized fractures is likely related to the rift-influenced tectonics during the Permian-Triassic. It is especially related to the intrusion of magma into the weakened southwest part of the Fennoscandian Shield during the Early Carboniferous. The formation of the NW-SE-oriented dolerite dikes cross-cutting the bedrock of Skåne was associated with hydrothermal activity mobilizing many of the elements found as fracture fillings today, i.e., calcite, fluorite, galena, and pyrite.

Despite the observed high amount of fractures, only five production zones (2750$2760 \mathrm{~m}, 2935-2945 \mathrm{~m}, 3125-3135 \mathrm{~m}, 3350-3362 \mathrm{~m}$, and 3464-3474 m) were surprisingly identified in the PLT surveys (cf. Fig. 6). Explanations for this could be that the rock mass is tight due to high rock stresses and/or that the fractures are to a greater extent mineralized. However, it is not possible to distinguish between sealed and open fractures from the obtained geophysical logs.

\section{Thermal properties}

The thermal gradient, heat production, and heat flow in the DGE-1 well have previously only been briefly described. The results in this study give a more detailed evaluation, which is compared with a selection of reference wells (Table 3). Outokumpo R-2500 and Gravberg-1 were selected as references for the upper crust in the Fennoscandian Shield. KTB was included as a reference for the central European crust. The Hunt well was included as an example for the thermal properties in the western margin of the Precambrian Canadian Shield and the LZ borehole in China for its similar succession of sedimentary strata overlying a Precambrian basement. Both these wells also constitute references regarding the calculation of heat flow and heat productivity from spectral

Table 3 Comparison of thermal data from the DGE-1 well with other deep boreholes drilled in the crystalline upper crust

\begin{tabular}{|c|c|c|c|c|c|c|}
\hline & DGE-1 & $\begin{array}{l}\text { Gravberg- } \\
1^{\mathrm{a}}\end{array}$ & $\begin{array}{l}\text { Outokumpu } \\
\mathrm{R}-2500^{\mathrm{b}}\end{array}$ & $\begin{array}{l}\text { KTB borehole, } \\
\text { Germanyc }\end{array}$ & $\begin{array}{l}\text { Hunt well, } \\
\text { Western } \\
\text { Canada }\end{array}$ & $\begin{array}{l}\text { LZ borehole, } \\
\text { China }^{f}\end{array}$ \\
\hline Depth, m & 3700 & 6957 & 2516 & 4000 & 3518 & 2363 \\
\hline $\begin{array}{l}\text { Temperature, } \\
{ }^{\circ} \mathrm{C}\end{array}$ & 85 & 116 & 40 & 119 & 95 & 47 \\
\hline $\mathrm{Q}, \mathrm{mW} / \mathrm{m}^{2}$ & $58^{g}$ & 50 & $40-45$ & 85 & 72 & 51 \\
\hline $\begin{array}{l}\text { Gradient, }{ }^{\circ} \mathrm{C} / \\
\mathrm{km}\end{array}$ & $22-24$ & $14-18$ & $14-17$ & 28 & 24 & 20 \\
\hline $\mathrm{K}, \mathrm{W} /(\mathrm{m} \mathrm{K})$ & $2.5-3.6$ & 3.4 & $2.5-3.3$ & $2.5-3.6^{d}$ & $2.2-3.6$ & 2.5 \\
\hline$A, \mu \mathrm{W} / \mathrm{m}^{3}$ & $5.8^{9}$ & $2-5$ & $1.6-5.4$ & $0.8-6.3^{d}$ & 0.9 & $2.9-3.4$ \\
\hline $\begin{array}{r}\text { Dominating } \\
\text { rock types }\end{array}$ & $\begin{array}{l}\text { Gneiss, } \\
\text { granite, } \\
\text { metabasite }\end{array}$ & Granite & $\begin{array}{l}\text { Meta- } \\
\text { sediments } \\
\text { Pegmatitic } \\
\text { granite, ultra- } \\
\text { mafic rocks }\end{array}$ & $\begin{array}{l}\text { Paragneiss, } \\
\text { hornblende gneiss, } \\
\text { amphibolite }\end{array}$ & $\begin{array}{l}\text { Gneiss, } \\
\text { granite }\end{array}$ & $\begin{array}{l}\text { Gneiss, } \\
\text { granite } \\
\text { mylonite }\end{array}$ \\
\hline
\end{tabular}

a Aldahan et al. (1991), bukkonen et al. (2011), 'CEmmermann and Lauterjung (1997), 'S Szalaiová et al. (2015), e'Majorowicz et al. (2014), ${ }^{f}$ Jiang et al. (2016), ${ }^{g}$ Weighted average 


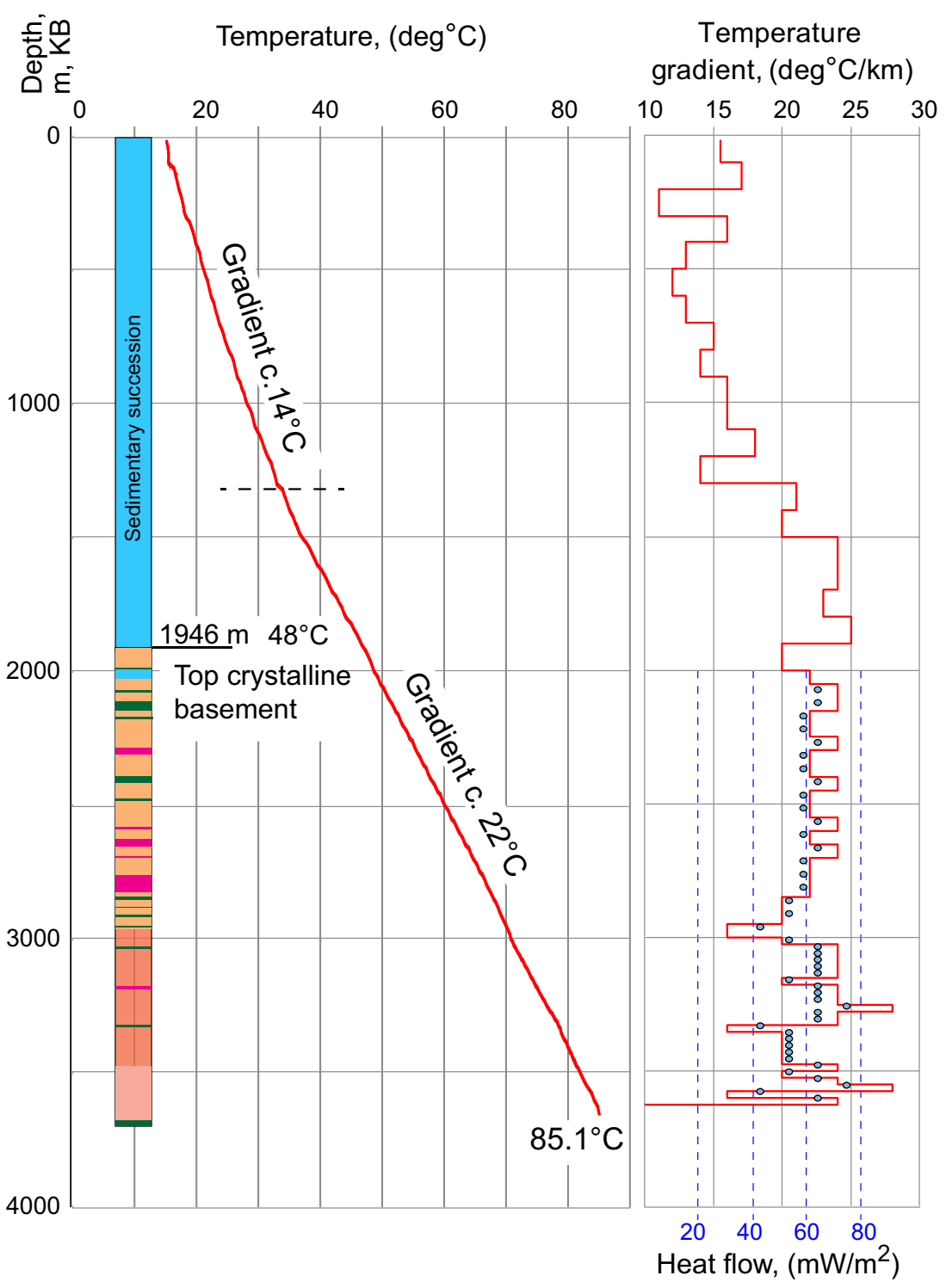

Fig. 8 Graphs showing the temperature profile and temperature gradients in the DGE-1 well. The calculated heat flow is shown for the crystalline section below $2000 \mathrm{~m}$

gamma ray logs. The thermal data from these reference wells enable an evaluation of the significance of the thermal properties in the DGE-1 well from a broader perspective.

\section{Thermal gradient}

The bottomhole temperature in the DGE-1 borehole is $85.1{ }^{\circ} \mathrm{C}$ and the mean temperature gradient in the crystalline basement between 1946 and $3700 \mathrm{~m}$ is $22{ }^{\circ} \mathrm{C} /$ $\mathrm{km}$. On a more detailed scale, the gradient varies between 16 and $28^{\circ} \mathrm{C} / \mathrm{km}$ (Fig. 8). The observed gradient is high in comparison to temperature gradients noted in other deep wells in the Fennoscandian basement. For example, the temperature gradient in 
the $6957 \mathrm{~m}$ deep borehole Gravberg-1 varies between 14 and $18{ }^{\circ} \mathrm{C} / \mathrm{km}$ (Juhlin et al. 1998). In the Outokumpu R-2500 research borehole in Finland, the gradient is in the same range (Table 3; Kukkonen et al. 2011). A slightly higher gradient of $20^{\circ} \mathrm{C} / \mathrm{km}$ was observed for the $2500 \mathrm{~m}$ deep COSC-1 borehole in the Swedish Caledonides in west central Sweden (Lorenz et al. 2015). The significantly higher gradient in the DGE-1 well fits with thermal models of the southwest margin of the Fennoscandian Shield and the Sorgenfrei-Tornquist Zone, with gradients between 20 and $24{ }^{\circ} \mathrm{C} / \mathrm{km}$ in the upper crust in, hence, significantly higher than for the interior parts of the shield (Balling 1995). The gradients in the crystalline section of the DGE-1 well are also comparable to the gradients noted in the KTB borehole in the upper central European crust in Germany. Likewise, the Hunt well in the Precambrian granitic basement of the western margin of the Canadian Shield displays similar gradients (Table 3).

It is also notable that the temperature gradient in the sedimentary succession down to c. $1450 \mathrm{~m}$ depth is considerably lower than expected (Fig. 8). Normally, the gradient in the Mesozoic sedimentary succession in southwest Skåne is considerably higher than the $14{ }^{\circ} \mathrm{C} / \mathrm{km}$ measured in the DGE-1 well. Normally, the temperature gradients are $28-32{ }^{\circ} \mathrm{C} / \mathrm{km}$ in other wells located in the sedimentary succession in southwest Skåne (Erlström et al. 2018). Between $1450 \mathrm{~m}$ and the top of the basement, the gradients in the sedimentary succession are the same as the ones in the crystalline basement. The temperature recorded in the upper part of the basement at c. $2000 \mathrm{~m}$ depth is only c. $48{ }^{\circ} \mathrm{C}$, which is considerably lower than what is noted at similar depths further out in the Danish Basin. Normal temperatures at $2000 \mathrm{~m}$ are here between 60 and $65^{\circ} \mathrm{C}$ (Erlström et al. 2018). The low gradients in the upper sedimentary succession down to c. $1450 \mathrm{~m}$ seems to be linked to the zone of strongly dipping and faulted rock blocks, which, in some way, seems to have influenced the temperature profile.

\section{Heat production}

The heat production $(A)$ for the crystalline section $(1977-3697 \mathrm{~m})$ is calculated using the concentrations of the radiogenic isotopes of uranium (U), thorium (Th), and potassium (K) from the spectral gamma ray log. The top of the logged interval is $1927.6 \mathrm{~m}$; however, the data quality down to $1977 \mathrm{~m}$ is poor and, therefore, not used in the calculations of the heat production. The concentrations of potassium and thorium differ significantly between the metabasite-amphibolite and gneiss-granite rock types. However,

Table 4 Compilation of the average potassium (K), thorium (Th), and uranium (U) concentrations $(C)$ and average heat production $(A)$ based on the spectral gamma ray log for the crystalline bedrock interval between 1977 and $3697 \mathrm{~m}$ in DGE-1

\begin{tabular}{lllll}
\hline Rock type and intervals & $\begin{array}{l}\text { Avg. conc. } \\
\text { potassium, \% }\end{array}$ & $\begin{array}{l}\text { Avg.conc. } \\
\text { thorium, ppm }\end{array}$ & $\begin{array}{l}\text { Avg. conc. } \\
\text { uranium, ppm }\end{array}$ & $\begin{array}{l}\text { Avg. heat } \\
\text { production }(\boldsymbol{A}) \text {, } \\
\boldsymbol{\mu W} / \mathbf{m}^{\mathbf{3}}\end{array}$ \\
\hline $\begin{array}{l}\text { Intervals of metabasite, amphibo- } \\
\text { lite, and dolerite }\end{array}$ & 1.3 & 12.5 & 15.0 & 5.4 \\
$\begin{array}{l}\text { Intervals of gneiss and granite } \\
\text { Interval: 1977-2980 m }\end{array}$ & 4.4 & 22.6 & 16.0 & 5.9 \\
Interval: 2980-3697 m & 3.6 & 24.8 & 15.9 & 7.6 \\
Complete section: $1977-3697 \mathrm{~m}$ & 3.9 & 15.5 & 8.7 & 3.4 \\
\hline
\end{tabular}


the uranium content is generally high in both rock types (Table 4). Concentrations of $20-25 \mathrm{ppm}$ are frequently noted for the interval between 2150 and $2980 \mathrm{~m}$. Below $2980 \mathrm{~m}$, the uranium concentration is significantly lower (Fig. 7). The intervals with relatively high uranium concentrations are consequently characterized by high heat production, commonly reaching up to $8 \mu \mathrm{W} / \mathrm{m}^{3}$. The average of the heat production for the various rock types and the complete section is between 5.41 and $5.95 \mu \mathrm{W} / \mathrm{m}^{3}$ (Table 4). This is high in comparison to most of the values presented in the reference wells (cf. Table 3). However, the average heat production is significantly lower below $2980 \mathrm{~m}$ (Fig. 7). This is consistent with in the overall lower average concentrations of the radiogenic isotopes and the change into more homogeneous gneiss-granite bedrock. In the relatively heterogeneous bedrock between 1977 and $2980 \mathrm{~m}$, the average heat productivity is $7.6 \mu \mathrm{W} / \mathrm{m}^{3}$ while being less than half of that value in the section below (Table 4). In the interval below $2980 \mathrm{~m}$, there are also sections with heat production reaching only c. $1.0 \mu \mathrm{W} / \mathrm{m}^{3}$.

The relatively high uranium concentration and corresponding high heat production over the 2150-2980 m interval is interpreted to relate to the heterogenous succession of gneisses with a high amount of dark minerals. However, since no detailed mineralogical or chemical studies have been performed on the cuttings, the underlying cause of the high uranium concentration remains uncertain.

\section{Heat flow}

Most of the calculated heat flow is between 55 and $67 \mathrm{~mW} / \mathrm{m}^{2}$ giving an average heat flow is $58.2 \mathrm{~mW} / \mathrm{m}^{2}(\mathrm{SD}=6.7)$. This is close to the heat flow between 60 and $70 \mathrm{~mW} / \mathrm{m}^{2}$, which is commonly assessed for other deep boreholes in the Danish Basin on the southwest margin of the Fennoscandian Shield. In the central parts of the shield, the heat flow is generally less with values normally between 40 and $50 \mathrm{~mW} / \mathrm{m}^{2}$ (Balling 1995). This is verified by information from the Gravberg-1 borehole in central Sweden and the Outokumpu R-2500 research borehole in Finland (Table 3; Aldahan et al. 1991; Kukkonen et al. 2011). A heat flow model of the Eugeno geotravese (EUGENO-s working group 1988; Balling 1995), crossing the southwest shield margin, also supports a heat flow in the upper crust in the Sorgenfrei-Tornquist Zone like the ones observed in the DGE-1 well. If the same average thermal conductivity is used as for the modelling of the Eugeno geotraverse [i.e., $3.0 \mathrm{~W} /(\mathrm{m} \mathrm{K})$; Balling (1995)], an even better fitting heat flow of 62.4 $\mathrm{mW} / \mathrm{m}^{2}(\mathrm{SD}=7.4)$ is obtained for DGE-1.

The relatively high heat flow in the southwest shield margin including the SorgenfreiTornquist Zone and the Danish Basin is interpreted to be caused by a higher heat flux from the upper mantle, as the crystalline crust is considerably less thick in comparison to the interior shield provinces (Balling 1995). So far, there are a few heat flow determinations from boreholes deeper than $1000 \mathrm{~m}$ in the crystalline bedrock of the Fennoscandian Shield. Deeper boreholes located in the shield margin, besides DGE-1, are exclusively in the sedimentary succession in the Danish Basin. The heat flow information from the crystalline section in the DGE-1 well, representing depths below which paleoclimatic effects can be neglected (c. 1500 m; cf. Kukkonen and Šafanda 1996; Balling 1995), thus constitutes an important source of information, which, in this case, 


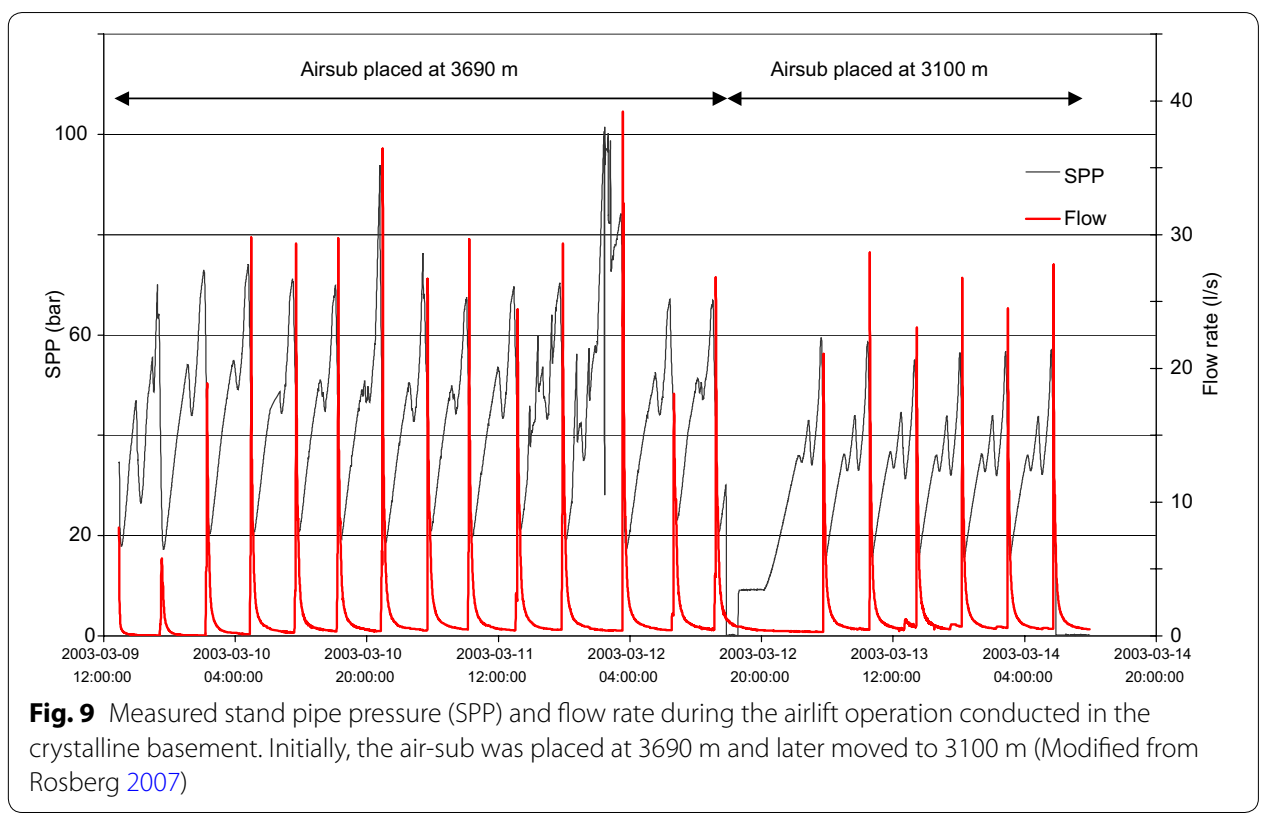

strengthens the heat flow models for the shield margin zone and the Sorgenfrei-Tornquist Zone presented by Balling (1995).

\section{Hydraulic properties}

In all, 19 airlifts were conducted over a period of 5 days, and the total formation fluid volume produced during the test was $664 \mathrm{~m}^{3}$. The airflow rate varied between 19.8 and $31.1 \mathrm{~m}^{3} / \mathrm{min}(700-1100 \mathrm{cfm})$. The air pressure measured in the stand pipe and the production flow rate acquired during the airlift operation are presented in Fig. 9. No consistent flow rate was reached during the test; instead, slugs of aerated formation fluid were lifted out of the well. The flow rate during each specific airlift varied between 0.6 and $2.5 \mathrm{l} / \mathrm{s}$, with an average value of $1.7 \mathrm{l} / \mathrm{s}$. The flow rate was calculated as the volume produced during each airlift divided by the time between the actual airlift and the previous airlift. Normally, it took around five and a half hours between two airlifts. Measurement of the formation fluid gave a density of $1200 \mathrm{~kg} / \mathrm{m}^{3}$. It is difficult to evaluate the exact hydraulic formation properties from the acquired data, since no downhole pressure measurements were performed.

Instead, the best available data for estimating the transmissivity and hydraulic conductivity are the data acquired from a 3 day long period with injection and fall-off tests. The recorded injection rate and pressure are shown in Fig. 10a. The perturbations in the injection data are caused by mud pump failures. The average injection rate was $2.75 \mathrm{l} / \mathrm{s}$ with a gradually increasing injection pressure. The injection pressure reached almost 200 bar before the second injection test terminated, which was a necessary measure as the maximum pressure rating of the mud pump was 205 bar.

In Fig. 10b, the acquired pressure versus time is presented in a semi-logarithmic figure. It can be seen that there are perturbations in the data obtained during the test, which can influence the analysis of the transmissivity. However, if straight line is fitted 

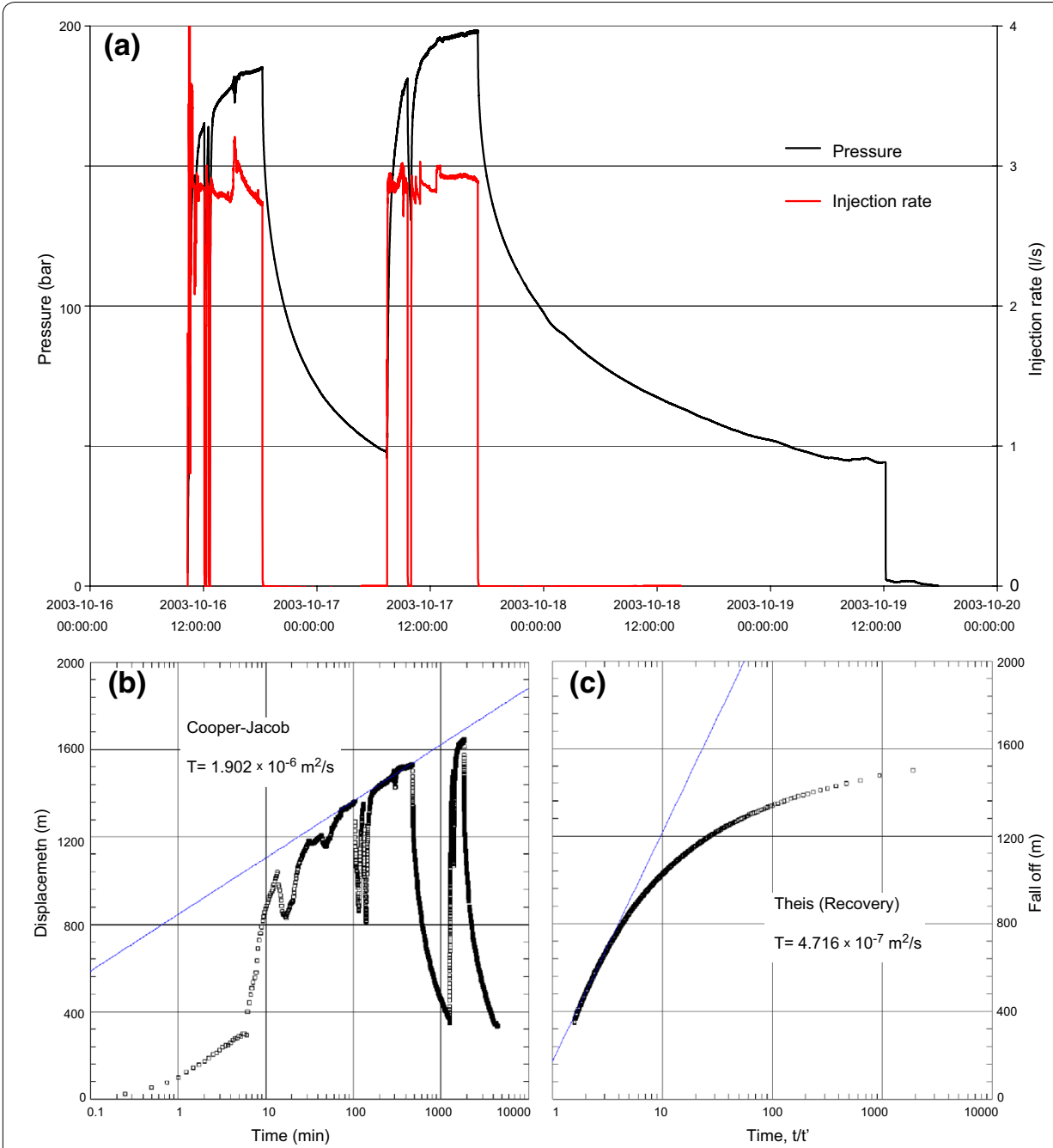

Fig. 10 a Recorded data from injection and fall-off tests conducted in the open-hole section between 3198 and $3701.8 \mathrm{~m}$. b Semi-logarithmic plot of the acquired pressure data, converted from bar to meters of water column. A straight line is fitted to the data for the first injection test and the Cooper-Jacob method is applied for estimating the transmissivity. c Transmissivity estimated from the first fall-off using Theis recovery method (Modified from Rosberg 2006)

to the data, between 70 and $500 \mathrm{~min}$ are rough values of the transmissivity which can be estimated as $1.9 \times 10^{-6} \mathrm{~m}^{2} / \mathrm{s}$ by, e.g., applying the Cooper-Jacob method (Cooper and Jacob 1946). A similar value can be calculated from the second injection tests. It is difficult to evaluate how representative the calculated value is due to the perturbations in the data. There are no perturbations in the fall-off data, and the data have been used to obtain a rough estimate of the transmissivity by applying Theis recovery method (Theis 1935). The estimation of the transmissivity from the first fall-off test is $4.7 \times 10^{-7} \mathrm{~m}^{2} / \mathrm{s}$, see Fig. $10 \mathrm{c}$, and $5.2 \times 10^{-7} \mathrm{~m}^{2} / \mathrm{s}$ from the second fall-off test (Rosberg 2006). The longest straight-line segment has been used for the transmissivity estimation. There are more options to fit a straight line to the fall-off data, which can yield higher transmissivity values, but whether they are more representative or not is hard to assess. In Fig. 10c, it can also be seen that the data in general are forming a 
curved line and not a straight line. A possible explanation for this can be that a fractured reservoir is tested, and during the pressure, fall-off, parts of the fractures are closing due to the decrease in fluid pressure. The average transmissivity value estimated from the two fall-off tests is used in the following discussion. The estimated transmissivity is 12 times lower in comparison to the transmissivity presented in Stober and Bucher (2005), where the well test was conducted in a 4-km-deep well located in crystalline basement and with an open section of $150 \mathrm{~m}$. A minimum value of the hydraulic conductivity is estimated as $9.9 \times 10^{-10} \mathrm{~m} / \mathrm{s}$ using the average transmissivity value and the length of the $504 \mathrm{~m}$ open hole. Juhlin (2004) reported similar hydraulic conductivity values, between $10^{-9}$ and $10^{-10} \mathrm{~m} / \mathrm{s}$, for the almost 7-km-deep Gravberg-1 and Stenberg-1 wells in central Sweden. The same order of hydraulic conductivity values is also presented in Bucher and Sober (2016) for the part below $3000 \mathrm{~m}$ in the Urach 3 well. No hydraulic conductivity values are presented below $1000 \mathrm{~m}$ for the Outokompu well; Kukkonen et al. (2011) consider this part as practically impermeable. However, the actual hydraulic conductivity in DGE-1 well is judged to be higher, since it is likely that only parts of the open hole is hydraulically active during the injection. This is also supported by the PLT survey which revealed that mainly two zones, $3350-3362 \mathrm{~m}$ and $3464-3474 \mathrm{~m}$, are hydraulically active intervals. A much higher hydraulic conductivity, $2.3 \times 10^{-8} \mathrm{~m} / \mathrm{s}$, is calculated if merely the thickness of these two intervals is divided with the estimated transmissivity. However, it is hard to evaluate the number of hydraulically active intervals during the injection test without running a flowmeter logging or similar.

Attempts were made to increase the inflow from the crystalline basement section by treating the open section with hydrochloric acid as well as perforating one of the cased sections, 3125-3135 m, of the crystalline basement. A potential inflow from this upper section was previously evaluated from one of the PLT surveys. However, these actions did not increase the production rate. Unfortunately, the project budget restricted testing of other promising production zones located in the cased part of the crystalline basement; see, e.g., zones marked as not tested in Fig. 6.

\section{Fluid characteristics}

The chemical signature of fluids in the upper crust is commonly the result from a combination of several chemical reactions between the host rock and the fluid, as well as influences from meteoric flushing and relict-trapped basinal fluids (Bucher and Stober 2010). The specific fluid-rock interaction is also likely greatly influenced by the tectonic history and the fracture framework and genetics. Considering the complex tectonic history of the Romeleåsen Fault Zone, it gives a fluid signature that is likewise difficult to understand.

In a relatively stable continental crust, the formation fluid in deep boreholes is generally characterized as a brine fluid with increasing chloride content with depth. In DGE-1, the analyzed fluid from the open-hole section between 3198 and $3701.8 \mathrm{~m}$ is characterized by a very high chloride content (Table 5 ). The analysis, furthermore, indicates that it is not a typical NaCl-brine but also includes a significant amount of $\mathrm{CaCl}_{2}$. Bucher and Stober (2010) state that fluids in gneisses and granites are normally $\mathrm{NaCl}$ brines, whereas amphibolitic rocks contains a significant $\mathrm{CaCl}_{2}$ component. A high $\mathrm{Ca} / \mathrm{Na}$ ratio 
Table 5 Summary of the results from the chemical analyses of the formation fluid sampled from the DGE-1 crystalline basement section between 3198 and $3701.8 \mathrm{~m}$

\begin{tabular}{|c|c|c|c|}
\hline \multicolumn{4}{|l|}{ Bench analysis } \\
\hline Electrical cond., $\mathrm{mS} / \mathrm{cm}$ & & & 174 \\
\hline $\mathrm{pH}$ & & & 6.6 \\
\hline Chloride, $\mathrm{Cl}$, mg/l & & & 120,000 \\
\hline $\mathrm{HCO}_{3}, \mathrm{mg} / \mathrm{l}$ & & & 54 \\
\hline $\mathrm{SO}_{4}, \mathrm{mg} / \mathrm{l}$ & & & 220 \\
\hline \multicolumn{4}{|c|}{ Results from ICP analysis } \\
\hline Element & $\mathrm{mg} / \mathrm{l}$ & Element & $\mathrm{mg} / \mathrm{l}$ \\
\hline Calcium, Ca & 42,000 & Cadmium, Cd & 0.0012 \\
\hline Magnesium, Mg & 87 & Cerium, Ce & 0.00007 \\
\hline Sodium, $\mathrm{Na}$ & 30,000 & Cesium, Cs & 1.4 \\
\hline Potassium, K & 880 & Gallium, Ga & 0.014 \\
\hline Strontium, Sr & 595 & Lanthanum, La & 0.00022 \\
\hline Lithium, Li & 5.4 & Mercury, Hg & 0.023 \\
\hline Iron, Fe & 0.53 & Molybdenum, Mo & 0.0047 \\
\hline Aluminum, Al & 0.032 & Nickel, Ni & 0.1 \\
\hline Manganese, Mn & 18 & Rhenium, Re & 0.00012 \\
\hline Bromide, $\mathrm{Br}$ & 38 & Rubidium, Rb & 6.3 \\
\hline Barium, Ba & 15 & Silicon, Si & 0.55 \\
\hline Boron, B & 5.1 & Silver, Ag & 0.00006 \\
\hline Chromium, $\mathrm{Cr}$ & 0.0015 & Sulfur, S & 72 \\
\hline Cobalt, Co & 0.0054 & Thallium, $\mathrm{Tl}$ & 0.140 \\
\hline Copper, Cu & 0.120 & Tin, Sn & 0.0021 \\
\hline lodine, I & 7.9 & Uranium, U & 0.00013 \\
\hline Lead, Pb & 0.004 & Zinc, Zn & 0.16 \\
\hline Lithium, Li & 5.4 & Zirconium, Zr & 0.0009 \\
\hline Antimony, Sb & 0.0062 & & \\
\hline
\end{tabular}

may also relate to albitization of the mafic host rocks, which is a common fluid-host rock interaction in upper crustal bedrock (Bucher and Stober 2010). This might indicate that the fluids in the DGE-1 well are predominantly fluids coming from fractured mafic rock intervals where albitization could be contributing to the high $\mathrm{Ca} / \mathrm{Na}$ ratio. Even if the mineralogical descriptions of the cuttings are incomplete, there are frequent notations of weathered feldspars (albitization), especially over fractured sections.

Despite that the sampling and analysis program was insufficient for a proper characterization of the fluids, the existing data show great compositional similarity to fluids coming from other deep boreholes in Germany, France, and Sweden. The Schoeller diagram in Fig. 11 displays that the fluids consist of similar high $\mathrm{Ca}-\mathrm{Na}-\mathrm{Cl}$ brines for all exemplified boreholes except Urach which has a significantly lower Ca-concentration. The fluids are also characterized by very low $\mathrm{Mg}$ concentrations. Interesting is that the FFC-1 data coming from a borehole in the Triassic sedimentary succession in southwest Skåne, c. $20 \mathrm{~km}$ to the southwest of the DGE-1 well, have an ionic composition that at first impression shows a similar ionic brine signature. However, the $\mathrm{Ca} /$ $\mathrm{Mg}$ ratio is significantly higher than for the fluids coming from the crystalline crust. The FFC-1 fluid does also show a very low $\mathrm{SO}_{4}$ concentration. The FFC-1 data are 


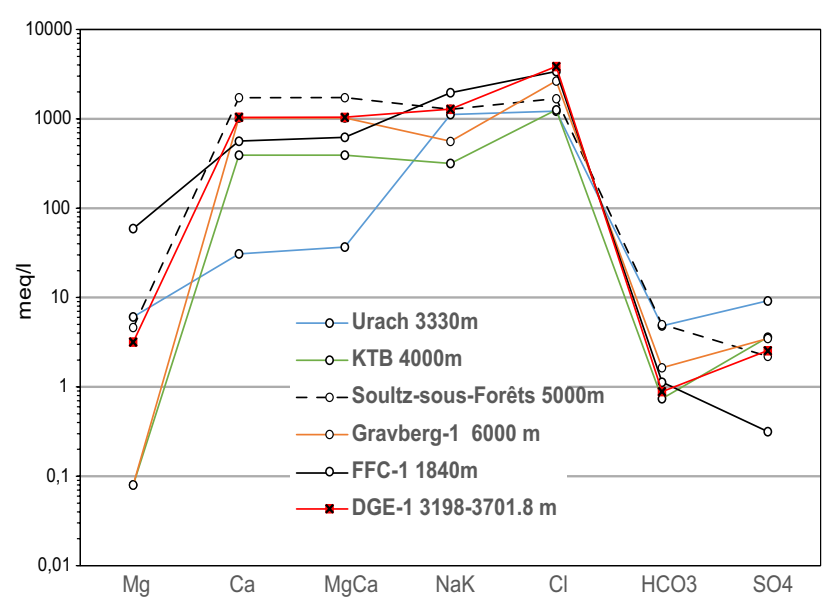

Fig. 11 Chemical concentration signatures of formation fluids plotted in a Schoeller diagram. The plot exemplifies deep boreholes in the upper crystalline crust, i.e., Urach (Stober and Bucher 2004), KTB (Stober and Bucher 2005), Soultz-sous-Forêts (Pauwels et al. 1993, Sanjuan et al. 2006), Gravberg-1 (Aldahan et al. 1991), and DGE-1. The FFC-1 data represent fluids coming in the Triassic succession at $1840 \mathrm{~m}$ depth in southwest Skåne (DONG 2003)

included here as an example of the ionic composition of the basinal fluids in the sedimentary bedrock, as it cannot be excluded that similar fluids may have influenced the ionic composition of the fluids in the DGE-1 well. Noteworthy, regarding the chemical data from the DGE-1 fluid, is furthermore that the $\mathrm{Cl} / \mathrm{Br}$ mass ratio is extremely high (3157) in comparison to a ratio of $<100$ that is common for fluids coming from some kilometre's depth in the upper crust (Stober and Bucher 1999; Bucher and Sober 2010). Ratios in the range of several thousand indicate external sources of the salinity, such as dissolution of halite in basinal sedimentary evaporitic strata (Stober and Bucher 1999). Evaporitic strata are almost absent in the sedimentary succession in SW Skåne. Minor beds are primarily found in the Triassic succession in the Höllviken Halfgraben, c. $50 \mathrm{~km}$ to the southwest of the DGE-1 site. Permian and Triassic evaporites are, however, common in the central parts of the Danish Basin to the west. How halite dissolution of these distal evaporites could influence the $\mathrm{Cl} / \mathrm{Br}$ ratio in the upper crystalline crust in DGE-1 is hard to understand. Anyway, the $\mathrm{Cl} / \mathrm{Br}$ ratio indicates some kind of external sources of the salinity, which still remains to be clarified.

\section{Lessons learnt}

An insufficient maximum temperature and poor yield due to poor hydraulic properties did not promote completion of the Lund deep geothermal project in the Romeleåsen Fault Zone. However, there are several lessons learnt concerning drilling and testing of the well.

A lesson learnt regarding the drilling operation was that air-based rotary drilling resulted in a slightly better ROP in comparison to the conventional mud-based rotary drilling. Although air-percussion drilling was even faster it was difficult to monitor if the hammer was functioning properly at great depths. However, too fast air drilling can result in problems with hole cleaning, which also was a lesson learnt as the 
drill string got stuck and a costly sidetracking operation had to be performed. It was also experienced that the air-based drilling often resulted in a great mixing of cuttings, which made the geological sampling and description difficult to perform. It is also unclear if there are any effects of the rock mass, such as chemical reactions causing precipitations inhibiting the hydraulic characteristics of fractures when using airbased drilling. Similar processes may have occurred during the airlift operation.

The DGE-1 well demonstrates that the Precambrian basement at great depth in the Danish Basin close to the Romeleåsen Fault Zone has a composition like the one found on the Romeleåsen Ridge. A few oil and gas prospecting wells in the marginal parts of the Danish Basin in SW Skane reaching the uppermost part of the Precambrian basement also indicate a rock mass dominated by gneiss, metabasite, and dolerite. Therefore, future deep drilling projects into the basement in SW Skåne could expect a distribution of rock types like the ones in the DGE-1 well.

The compensated spectral gamma ray log proved to be very useful in defining where metabasite and dolerite occur in the gneiss- and granite-dominated rock mass. The U/K, $\mathrm{Th} / \mathrm{K}$, and $\mathrm{U} / \mathrm{Th}$ ratios were also important as to identify where mineralogical changes in the main rock mass occur.

Microfractures and fracture fillings were frequently observed in the cuttings. Zones of weakness in the rock mass, which likely relate to high amount of fractures, were also identified by the Caliper and Sonic Velocity log. The fracture fillings were found to greatly resemble the ones identified in the gneiss on the Romeleåsen Ridge. However, the amount of hydraulically open fractures and zones proved to be lower than expected. The reason behind this is still uncertain. Either high rock stresses and/or a predominance of sealed fractures could be the underlying cause.

One experience from the DGE-1 exploration project is, furthermore, that cores are necessary, at least over parts of the target section, as to be able to perform a proper classification and characterization of the rock mass and the fracturing. It is also a necessity to have cores for determining hydraulic and thermal properties of the crystalline bedrock. A lesson learnt is also that results from a density log is required to achieve a better calculation of the heat production. The quality of the performed evaluation of the thermal properties would improve if these sources of information were available.

It was observed that airlifting as a hydraulic testing method created a rapid drawdown, and sensitive adjustments of the airflow were necessary. This often results in undulations in the acquired pressure and flow rate, before the optimal air inflow can be found. Thus, airlifting often yields more noisy data in comparison with using a submersible pump (e.g., Rosberg 2007). It is much easier to adjust a submersible pump for obtaining a consistent flow rate and to diminish perturbations in the recorded pressure, as well as to avoid oxygenation of the formation and formation fluid.

It was found that the hydraulic properties, such as hydraulic conductivity and transmissivity, for the tested crystalline basements are low. Only five minor intervals, interpreted from the PLT surveys, contributed to the inflow to the well. The fracture frequency and fracture zones are generally hard to interpret from the different logging probes used. Unfortunately, no acoustic televiewer was run from which additional information about the fractures, such as distribution and characteristics, could be obtained. The number of fractures is valuable information for explaining the low 
hydraulic conductivity value. Issues like if most of the fractures are sealed and thereby not contributing to the flow into the well could be discussed in a more accurate way using the additional information about the fractures. The same information is also important for assessing the high chloride content in the formation fluid. It would have been beneficial to in a better way identifying the fracture zones contributing to the inflow and test these zones separately by, for example, conducting packer testing in combination with depth-specific sampling and analysis of the formation fluids. As it is now, the data available can only be used for discussing the hydraulic properties of the entire open-hole section and not individual fractures/fracture zones.

\section{Conclusions}

It can be concluded that the drilling and testing of DGE-1 provides new geoscientific information about the upper crust in the Fennoscandian Shield margin and the Romeleåsen Fault Zone. This information is valuable for future deep geothermal projects focussing on the upper crystalline crust in the region. The project has shown that air-based drilling is the most efficient method for deep drilling of the crystalline basement in this geological setting. The results from the evaluation of the thermal properties verify an average thermal gradient $\left(22^{\circ} \mathrm{C} / \mathrm{km}\right)$ and average heat flow $\left(58 \mathrm{~mW} / \mathrm{m}^{2}\right)$ that are higher in comparison to other deep wells in the Fennoscandian Shield. Noteworthy is that the average heat production $\left(5.8 \mu \mathrm{W} / \mathrm{m}^{3}\right)$ is significantly higher than in other deep wells located in similar crystalline rock. The obtained transmissivity $\left(5.0 \times 10^{-7} \mathrm{~m}^{2} / \mathrm{s}\right)$ and hydraulic conductivity $\left(9.9 \times 10^{-10} \mathrm{~m} / \mathrm{s}\right)$ are low from a production perspective, but the values are within the same range as for the values obtained in deep wells such as Gravberg- 1 and Urach-3. In addition, the sampled fluid in DGE-1 showed a compositional similarity to fluids sampled in deep wells located in Germany, France and Sweden. Significant is the relatively high $\mathrm{Ca} / \mathrm{Na}$ ratio which is interpreted to be caused by albitization of the feldspars in the crystalline rocks.

\section{Authors' contributions}

Both authors contributed to the synopsis, background, and method descriptions. ME compiled and interpreted the geological and geophysical data. JER provided data and evaluated the drilling and testing operations. Both authors contributed to the discussion, conclusions, and illustrations. Both authors read and approved the final manuscript.

\section{Author details}

${ }^{1}$ Engineering Geology, Faculty of Engineering, Lund University, Box 118, 22100 Lund, Sweden. ${ }^{2}$ Geological Survey of Sweden, Kiliansgatan 10, 22350 Lund, Sweden. ${ }^{3}$ Department of Geology, Lund University, Sölvegatan 12, 223 62 Lund, Sweden.

\section{Acknowledgements}

Prof. Leif Johansson is thanked for valuable discussions regarding the fracture genetics and mineralogy. He is also thanked for providing the photograph in Fig. 3. Gratitude is also expressed to the retired State Geologist Hugo Wikman for his petrological judgement of the various rock types occurring in the cuttings. Gerhard Barmen is thanked for valuable comments on the manuscript. We also thank Virgil Welch, Ulf Sivhed, Peter Jonsson, and Per-Gunnar Alm for their contributions during drilling and testing of the DGE-1 well. The late Prof. em. Leif Bjelm and Derek Howard-Orchard are remembered for their valuable work with the Lund deep geothermal project.

\section{Competing interests}

The authors declare that they have no competing interests.

\section{Availability of data and materials}

The geophysical seismic survey data, wire-line data, cuttings material and results from hydraulic tests, and well reports used for this study are available at the Geological Survey of Sweden and at the Department of Engineering Geology at Lund University. In the DGE-1 well, there is today a bridge plug installed at $2570 \mathrm{~m}$, which seals off the lower parts of the Precambrian basement sections. The upper part of the well down to the bridge plug is accessible. The well is presently accessible and located in a locked concrete cellar. 


\section{Funding}

The work regarding the evaluation has been funded by the Geological Survey of Sweden and the Department of Engineering Geology at Lund University.

\section{Publisher's Note}

Springer Nature remains neutral with regard to jurisdictional claims in published maps and institutional affiliations.

Received: 12 December 2018 Accepted: 21 March 2019

Published online: 05 April 2019

\section{References}

Aldahan AA, Castañ J, Collini B, Gorody T, Juhlin C, Sandstedt H. Scientific summary report of the deep gas drilling project in the siljan ring impact structure. Vattenfall Rep. 1991;1991:1-257.

Alm P-G, Bjelm L. Towed array seismic exploration of the Tornqvist zone In: Thirty-first Workshop on geothermal reservoir engineering Stanford University, Stanford, California, January 30-February 1, 2006, SGP-TR-179; 2006a. p. 459-64.

Alm P-G, Bjelm L. Temperature logging in perforated wells In: Thirty-first Workshop on geothermal reservoir engineering Stanford University, Stanford, California, January 30-February 1, 2006, SGP-TR-179; 2006b. p. 465-70.

Andolfsson T (2013) Analyses of thermal conductivity from mineral composition and analyses by use of thermal conductivity scanner: a study of thermal properties in Scanian rock types, vol. 341. Master of Science thesis Department of Geology, Lund University. p. 1-27.

Arshavskaya NI, Galdin NE, Karus EW, Kuznetsov OL, Lubimova EA, Milanovsky SY, Nartikoev VD, Semashko SA, Smirnova EV. Geothermic investigations. In: Kozlovsky YA, editor. The superdeep well of the Kola Peninsula. Berlin: Springer; 1984. p. 387-93.

Balling N. Heat flow and thermal structure of the lithosphere across the Baltic Shield and northern Tornquist Zone. Tectonophysics. 1995;244:13-50.

Bjelm L. Country Update, Sweden In: Proceedings world geothermal congress, Antalya, Turkey 24-29 April 2005; 2005.

Bjelm L. Under Balanced Drilling and Possible Well Bore Damage in Low Temperature Geothermal Environments. In: Thirty-First Workshop on Geothermal Reservoir Engineering Stanford University, Stanford, California, January 30 February 1, 2006, SGP-TR-179; 2006. p. 67-72.

Bjelm L, Lindeberg L. Long-term experience from a heatpump plant in Lund, Sweden, using a low-temperature geothermal aquifer. Lund University report; 1994.

Bjelm L, Rosberg J-E. Recent geothermal exploration for deep seated sources in Sweden. In: Transactions GRC. Annual meeting september 10-13; 2006, San Diego California, USA; 30; 2006. p. 655-8.

Bjelm L, Hartlèn J, Röshoff K, Bennet J, Bruch H, Persson P-G, Wadstein P. Geotermisk energiutvinning i Skåne Slutrapport Etapp 1. Department of Engineering Geology, Lund University report, LUTVDG, TVGL-5013; 1977. p. 1-50. (in Swedish).

Bruton G, Land J, Moran D, Swadi S, Strachan R, Tørge K. Whipstock options for sidetracking. Oilfield Rev. 2014;26:16-25.

Bucher K, Stober I. Fluids in the upper continental crust. Geofluids. 2010;10:241-53.

Bucher K, Stober I. Large-scale chemical stratification of fluids in the crust: hydraulic and chemical data from the geothermal research site Urach, Germany. Geofluids. 2016;16:813-25.

Bücker C, Rybach L. A simple method to determine heat production from gamma-ray logs. Mar Pet Geol. 1996:13:373-5.

Chapman DS, Furlong KP. Thermal state of the continental lower crust. In: Fountain DM, Arculus RJ, Kay RW, editors. continental lower crust. Amsterdam: Elsevier; 1992. p. 179-99.

Cooper $\mathrm{HH}$, Jacob CE. A generalized graphical method for evaluating formation constants and summarizing well field history. Trans Am Geophys Union. 1946;27:526-34.

Directive 2009/28/EC. Directive of the European Parliament and of the Council of 23 April 2009 on the promotion of the use of energy from renewable sources and amending and subsequently repealing Directives 2001/77/EC and 2003/30/EC. Off J Eur Union. 2009:5.6:16-62.

DONG. Final Testing Report FFC-1, Geothermal project Malmö, Internal project report; 2003.

Emmermann R, Lauterjung J. The german continental deep drilling program KTB: overview and major results. J Geophys Res. 1997;102:18179-201.

Erlström M. Petrology and deposition of the lund sandstone, upper cretaceous, southwestern Scania. Geol Surv Sweden. 1990;Ca74:1-91.

Erlström M. Konceptuell geologisk modell av Romeleåsens förkastningszon mellan Lund och Dalby. Sveriges geologiska undersökning rapport; 08/1193/2001:1-16; 2002. (in Swedish).

Erlström M, Sivhed U. Well site report DGE-1. Geological descriptions and composite litholog. Geological survey of Sweden report; 08-1112/2002; 2003. p. 1-49.

Erlström M, Deeks N, Sivhed U, Thomas S. Structure and evolution of the Tornquist Zone and adjacent sedimentary basins in Scania and the southern Baltic Sea area. Tectonophysics. 1997:271:191-215.

Erlström M, Sivhed U, Wikman H, Kornfält KA. Beskrivning till berggrundskartorna 2D Tomelilla NV, NO, SV, SO, 2E Simrishamn NV, NO, 1 E Örnahusen NV. Sveriges geologiska undersökning; Af 212-214:1-141; 2004. (in Swedish with an English summary).

Erlström M, Boldreel LO, Lindström S, Kristensen L, Mathiesen A, Andersen MS, Nielsen LH. Stratigraphy and geothermal assessment of Mesozoic sandstone reservoirs in the Øresund Basin-exemplified by well data and seismic profiles. Bull Geol Soc Den. 2018:66:123-49.

EUGENO-s working group. Crustal structure and tectonic evolution of the transition between the Baltic Shield and the North German Caledonides. Tectonophysics. 1988;150:253-348. 
Gérard A, Genter A, Kohl T, Lutz P, Rose P, Rummel F. The deep EGS (Enhanced Geothermal System) project at Soults-sousForêts (Alsace, France). Geothermics. 2006;35:473-83.

Gregersen S, Leth J, Lind G, Lykke-Andersen $\mathrm{H}$. Earthquake activity and its relationship with geologically recent motion in Denmark. Tectonophysics. 1996;257:265-73.

Halling J. Inventering av sprickmineraliseringar i en del av Sorgenfrei-Tornquistzonen, Dalby stenbrott, Skåne. Master of Science thesis Department of Geology, Lund University, vol. 448; 2015. p. 1-36. (in Swedish).

Howard-Orchard D. Final Well Report Lund DGE\#1 Deep Geothermal Energy Project, Lunds Energi, Technical report; 2003.

Japsen P, Bidstrup T, Lidmar-Bergström K. Neogene uplift and erosion of southern Scandinavia induced by the rise of the South Swedish Dome. In: Doré AG, Cartwright JA, Stoker MS, Turner JP, White N, editors. Exhumation of the North Atlantic margin: timing, mechanism and implications for petroleum exploration. Geological Society of London, special publication, vol. 196. London: Geological Society; 2002. p. 183-207.

Jiang G, Tang X, Rao S, Gao P, Zhang L, Zhao P, Hu S. High-quality heat flow determination from the crystalline basement of south-east margin of North China Craton. J Asian Earth Sci. 2016;1 18:1-10.

Juhlin C. Overview of results from deep drilling in the Siljan Ring impact struct. In: American geophysical union, fall meeting 2004; Abstract ID. T43C-1347; 2004.

Juhlin C, Wallroth T, Smellie J, Leijon B, Eliasson T, Ljunggren C, Beswick J. The very deep hole concept—Geoscientific appraisal of conditions at great depth. Swedish Nuclear Waste Programme Technical Report SKB-TR-98-05; 1998

Kukkonen IT ed. Outokumpu deep drilling project 2003-2010. Geological Survey of Finland, Special paper 51; 2011.

Kukkonen IT, Šafanda J. Palaeoclimate and structure: the most important factors controlling subsurface temperatures in crystalline rocks. A case history from Outokumpo, eastern Finland. Geophys J Int. 1996;126:101-12.

Kukkonen IT, Rath V, Kivekäs L, Šafanda J, Cermak V. Geothermal studies of the Outokumpu Deep Drill Hole, Finland: vertical variation in heat flow and paleoclimatic implications. Phys Earth Planet Inter. 2011;188:9-25.

Lassen A, Thybo H. Neoproterozoic and Palaeozoic evolution of SW Scandinavia based on integrated seismic interpretation. Precambr Res. 2012;204-205:75-104.

Leary P, Malin P, Saarno T, Kukkonen I. Prospects for assessing enhanced geothermal system (EGS) basement rock flow stimulation by wellbore temperature data. Energies. 2017;10(12):1-33. https://doi.org/10.3390/en10121979.

Lorenz H, Rosberg J-E, Juhlin C, Bjelm L, Almqvist B, Berthet T, Conze T, Gee D, Klonowska I, Pascal C, Pedersen K, Roberts $\mathrm{N}$, Tsang C-F. COSC-1-drilling of a subduction-related allochthon in the Palaeozoic Caledonide orogen of Scandinavia. Sci Drill. 2015;19:1-11.

Majorowicz J, Chan J, Crowell J, Gosnold W, Heaman LM, Kück J, Nieuwenhuis G, Schmitt DR, Unsworth M, Walsh N, Weiders $\mathrm{S}$. The first deep heat flow determination in crystalline basement rocks beneath the Western Canadian Sedimentary Basin. Geophys J Int. 2014;197:731-47.

Malin P. st1 Deep heat project update; 2018. https://blog.smu.edu/geothermallab/2017/05/15/st1-deep-heat-drilling-toresume/. Accessed 20 Nov 2018.

MIT. The Future of geothermal energy: impact of enhanced geothermal systems (EGS) on the United States in the 21st Century: an assessment. Cambridge: Massachusetts Institute of Technology; 2006. p. 372.

OECD/IEA. Technology roadmap. Geothermal heat and power. Int Energy Agency Rep. 2011;2011:1-44.

Pauwels H, Fouillac C, Fouillac AM. Chemistry and isotopes of deep geothermal saline fluids in the Upper Rhine Graben: origin of compounds and water-rock interactions. Geochim Cosmochim Acta. 1993;57:2737-49.

Popov YA, Pribnow DFC, Sass JH, Williams CF, Burkhardt H. Characterization of rock thermal conductivity by high-resolution optical scanning. Geothermics. 1999;28:253-76.

Rosberg J-E. Flow test of a perforated deep dual cased well. In: Thirty-first Workshop on geothermal reservoir engineering Stanford University, Stanford, California, January 30-February 1, 2006, SGP-TR-179; 2006. p. 123-30.

Rosberg J-E. Testing, well development and evaluation of deep wells completed in Lund 2002-2005. Licentiate Thesis Engineering Geology Lund University, ISRN LUTVDG/TVTG-1022-SE, ISBN 978-91-976848-0-4; 2007.

Sanjuan B, Pinault JL, Rose P, Gerard A, Brach M, Braibant G, Crouzet C, Foucher JC, Gautier A. Geochemical fluid characteristics and main achievements about traces tests at Soultz-sous-Forêts (France). EHDRA Scientific Conference 2006, Soultz-sous-Forêts, France; 2006. p. 13.

Sivhed U, Wikman H, Erlström M. Beskrivning till berggrundskartorna 1C Trelleborg NV, NO, 2C Malmö SV, SO, NV, NO (in Swedish with an English summary). Sveriges geologiska Undersökning. Af 191-194,196,198; 1999. p. 1-143.

Stober I, Bucher K. Origin of salinity of deep groundwater in crystalline rocks. Terra Nova. 1999;11:181-5.

Stober I, Bucher K. Fluid sinks within the earth's crust. Geofluids. 2004;4:143-51.

Stober I, Bucher K. The upper continental crust, an aquifer and its fluid: hydraulic and chemical data from $4 \mathrm{~km}$ depth in fractured crystalline basement rocks at the KTB test site. Geofluids. 2005;5:8-19.

Szalaiová E, Rabbel W, Marquart G, Vogt C. Geothermal modelling of faulted metamorphic crystalline crust: a new model of the Continental Deep Drilling Site KTB (Germany). Geophys J Int. 2015;203:1039-53.

Tenzer H, Schanz U, Homeier G. HDR research programme and results of drill hole Urach 3 to depth $4440 \mathrm{~m}$ - the key for realisation of a HDR programme in southern Germany and northern Switzerland. In: Proceedings world geothermal congress. Kyushu-Tohoku, Japan May 28-June 10, 2000; 2000.

Theis $\mathrm{CV}$. The relation between the lowering of the piezometric surface and the rate and duration of discharge of a well using groundwater storage. Trans Am Geophys Union. 1935;16:519-24.

Thomas SA, Deeks NR. Seismic evidence for inversion tectonics in the strike-slip regime of the Tornquist Zone, Southern Baltic Sea. Zeitschrift fur geologisches Wissenschaften. 1994;22:33-45.

Wittig V, Bracke R, Hyun-Ick Y. Hydraulic DTH Fluid/Mud hammers with recirculation capabilities to improve ROP and hole cleaning for deep, hard rock geothermal drilling. In: Proceedings world geothermal congress; Melbourne, Australia 19-25 April 2015; 2015.

Wollenberg HA, Smith AR. Radiogenic heat production of crustal rocks: an assessment based on geochemical data. Geophys Res Lett. 1987;16:295-8. 